\title{
Federal Credit and Insurance Programs: Housing
}

\author{
John M. Quigley
}

This paper reviews the evolution of the major credit and insurance programs undertaken by the U.S. government in support of urban housing. As the review makes clear, the Federal Housing Administration (FHA), Veterans Administration, Federal National Mortgage Association, and Federal Home Loan Mortgage Corporation have played major roles in the development of liberal and efficient primary and secondary mortgage markets in the United States. The development of capacity in mortgage lending and securitization in the private sector does suggest, however, that federally subsidizing mortgage market activities can be restrained with little effect on homeownership - the principal goal of this federal activity. In particular, the orderly reduction in the mortgage investment activities of the government-sponsored enterprises (GSEs) and the imposition of guarantee fees on mortgage-backed securities insured by the GSEs are first steps in restraining federal activity. More generally, a concentration of FHA and GSE activity on first-time homebuyers would reduce federal risk exposure while preserving the economic rationale for government activity.

Federal Reserve Bank of St. Louis Review, July/August 2006, 88(4), pp. 281-309.

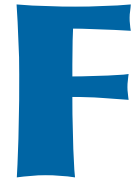

ederal policy affecting housing is dominated by indirect off-budget activities-tax expenditure policies and credit, insurance, and guarantee programs—rather than the direct subsidy of housing production or the payment of shelter allowances to deserving households. This paper reviews federal activity in providing credit and insurance for housing. I begin by reviewing mortgage insurance and guarantee programs: the Federal Housing Administration (FHA) and the Veterans Administration (VA). These large programs are administered by different cabinet agencies: the Department of Housing and Urban Development (HUD) and the Department of Veterans Affairs, respectively. ${ }^{1}$

I then review federally supported credit activities: the Federal National Mortgage Associa- tion (Fannie Mae), the Federal Home Loan Mortgage Corporation (Freddie Mac), and the Government National Mortgage Association (Ginnie Mae). Freddie Mac and Fannie Mae are government-sponsored enterprises (GSEs). Both are publicly chartered, privately owned corporations. They are regulated by the Office of Federal Housing Enterprise Oversight for financial safety and soundness and by HUD for compliance with their public mission. Ginnie Mae is a wholly owned government corporation within HUD.

For these organizations, I briefly recount their history and operations. I review their economic functions and highlight current issues about their

1 A third program, the Farm Service Administration, insures farms and some rural homes. It is administered by the Department of Agriculture.

John M. Quigley is professor of economics at the University of California, Berkeley. The author is grateful for the comments of Alan Auerbach, Charles Capone, Dwight Jaffee, Andreas Lehnert, Frank Nothaft, Robert Van Order, John Weicher, James Wilcox, and Susan Woodward and for the able assistance of Simon Firestone.

(C) 2006, The Federal Reserve Bank of St. Louis. Articles may be reprinted, reproduced, published, distributed, displayed, and transmitted in their entirety if copyright notice, author name(s), and full citation are included. Abstracts, synopses, and other derivative works may be made only with prior written permission of the Federal Reserve Bank of St. Louis. 


\section{Quigley}

\section{Figure 1}

\section{U.S. Housing Starts, 1900-2004}

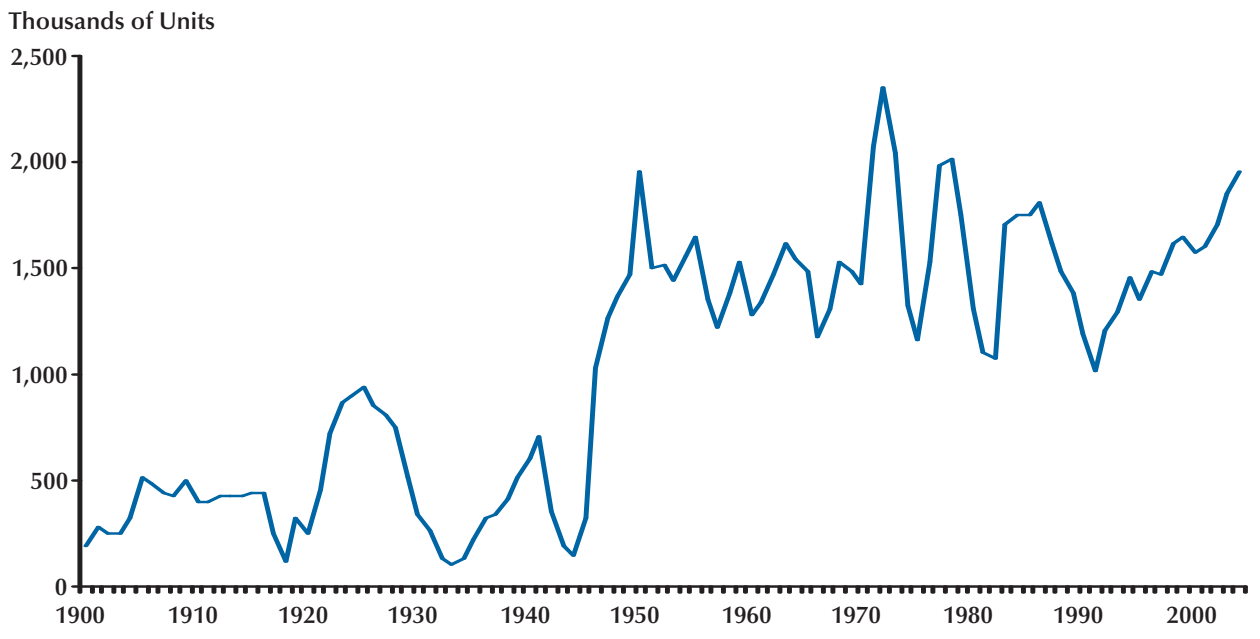

SOURCE: Doan (1997); www.census.gov/const/startsan.pdf.

roles in the housing system and the broader economy.

\section{FEDERAL INSURANCE AND GUARANTEE PROGRAMS}

Before the depression of the 1930s, home mortgage instruments were typically of short terms (3 to 10 years) with loan-to-value ratios (LTVs) of 60 percent or less. Mortgages were nonamortizable, requiring a balloon payment at the expiration of the term. The onset of the Great Depression engendered a liquidity crisis beginning in 1930, preventing renewal of outstanding contracts. Other borrowers were simply unable to make regular payments. The liquidity crisis affecting new mortgage loans, together with elevated default rates on existing loans, had catastrophic effects on housing suppliers as well as housing consumers.

Figure 1 shows the course of house building during the twentieth century. It reports the sustained boom in housing construction in the 1920s-peaking in 1925 but averaging more than 700,000 housing starts per year from 1920 through 1929. The figure also depicts the collapse of the housing market at the onset of the Great Depression. During the period 1930-35, housing starts declined by 75 percent, to about 193,000 per year.

Despite voluntary forbearance on the part of some lending institutions and mandated forbearance enacted by many state legislatures, the system of mortgage lending that existed in the early $1930 \mathrm{~s}$ continued to contract, and many lending institutions simply failed. The establishment of the Home Owners' Loan Corporation in 1933 within the Federal Home Loan Bank System (established a year earlier) provided stop-gap refinancing for a million mortgages. ${ }^{2}$ Passage of the National Housing Act of 1934 established the structure of home mortgage insurance and facilitated the growth of the modern system of mortgage finance in the United States.

The 1934 Act established the Federal Housing Administration (FHA) to oversee a program of home mortgage insurance against default. Insurance was funded by the proceeds of a fixed premium charged on unpaid loan balances. These

\footnotetext{
2 These measures are described in Doan (1997).
} 
revenues were deposited in Treasury securities and managed as a mutual insurance fund. Significantly, default insurance was offered on "economically sound" self-amortizing mortgages with terms as long as 20 years and with LTVs up to 80 percent.

Diffusion of this product across the country required national standardization of underwriting procedures. Appraisals were required, and borrowers' credit histories and financial capacities were reported and evaluated systematically. The modern standardized mortgage was born. ${ }^{3}$

The Mutual Mortgage Insurance Fund, which was established to manage the reserve of annual premiums, was required to be actuarially sound. This was generally understood to involve very small redistributions from high-income to lowincome mortgagees. (See, for example, Aaron, 1972.) By its original design, the FHA was clearly intended to serve the vast majority of homeowners. Initial loan amounts were restricted to be no larger than $\$ 16,000$ at a time when the median house price was $\$ 5,304 .^{4}$

Near the end of World War II, it was widely feared that the peacetime economy would return the housing market to its depression-era performance. From Figure 1, note that housing starts in 1944 were at about the same level as they had been a decade earlier. The VA loan program, passed as a part of the GI bill in 1944, rapidly evolved from a temporary "readjustment" program to a longrange housing program available to veterans for a decade or more after returning to civilian life. This transformation contributed to the boom in the residential construction industry that began in the late 1940s. Ultimately, a liberal program of veterans' home loans was established in 1950 and subsequently extended. In contrast to the insurance provided by the FHA, the VA provided a federal guarantee for up to 60 percent of the face value of a mortgage loan made to an eligible veteran, subject to a legislated maximum. The VA program facilitated loans by private lenders on favorable terms, with no down payments and with moderate interest rates.

\footnotetext{
3 See Green and Wachter (2005) for an extensive discussion of this history.

4 The FHA ceiling was reduced to $\$ 6,000$ in 1938 , but that level was still above the median house price at the time, $\$ 5,804$.
}

These two programs providing insurance and mortgage guarantees brought homeownership opportunities to middle class American households in a short space of time. As noted in Figure 1, since 1950, annual housing starts have rarely fallen below one million. Figure 2 reports the remarkable growth of mortgage originations attributable to these programs. In 1960, about $\$ 5$ billion in FHA-insured mortgages and $\$ 2$ billion in VA-guaranteed mortgages were issued. By 2003, about $\$ 165$ billion in FHA-insured mortgages and about $\$ 66$ billion in VA-guaranteed mortgages were issued. In real terms, FHA mortgage activity has quadrupled during the period since 1960 and VA originations have increased by 430 percent.

Over time, the fraction of mortgage originations attributable to the FHA and VA has declined systematically. Figure 3 reports that the fraction of originations (in dollar volume) insured by the FHA declined from as high as 25 percent in 1957 to a bit under 5 percent in 2004. Similarly, VAguaranteed mortgages declined from about a quarter of the value of originations in 1955 to a couple of percent in 2004. Overall, these programs accounted for over 40 percent of the dollar volume of originations in 1957 and 8 percent at the turn of this century.

The relative reduction in FHA and VA originations over time has arisen from two factors. First, the modern private mortgage market-mortgage banks and suppliers of private mortgage insurance-arose under the shadows of these public institutions. ${ }^{5}$ The behavior of consumers with long-term, low-interest-rate, government-insured mortgages made it clear that reliance on these liberal instruments to provide credit could be profitable activities for mortgage suppliers and private insurers. Default rates just aren't very high. This was not well-known or appreciated until the experience of FHA and VA mortgages was accumulated. Balances in the Mutual Mortgage Insurance Fund were easily observable to private actors. ${ }^{6}$ This

\footnotetext{
5 For example, in 1957, the Mortgage Guaranty Insurance Corporation became the first private mortgage guarantee firm established since the Great Depression.

6 The original structure of FHA insurance premiums-an annual premium against the unpaid mortgage balance-was changed to a fixed-percentage payment at closing (in 1983) and then to a sliding scale based on the LTV (in 1990).
} 


\section{Quigley}

\section{Figure 2}

\section{Value of FHA- and VA-Guaranteed Originations, 1935-2004}

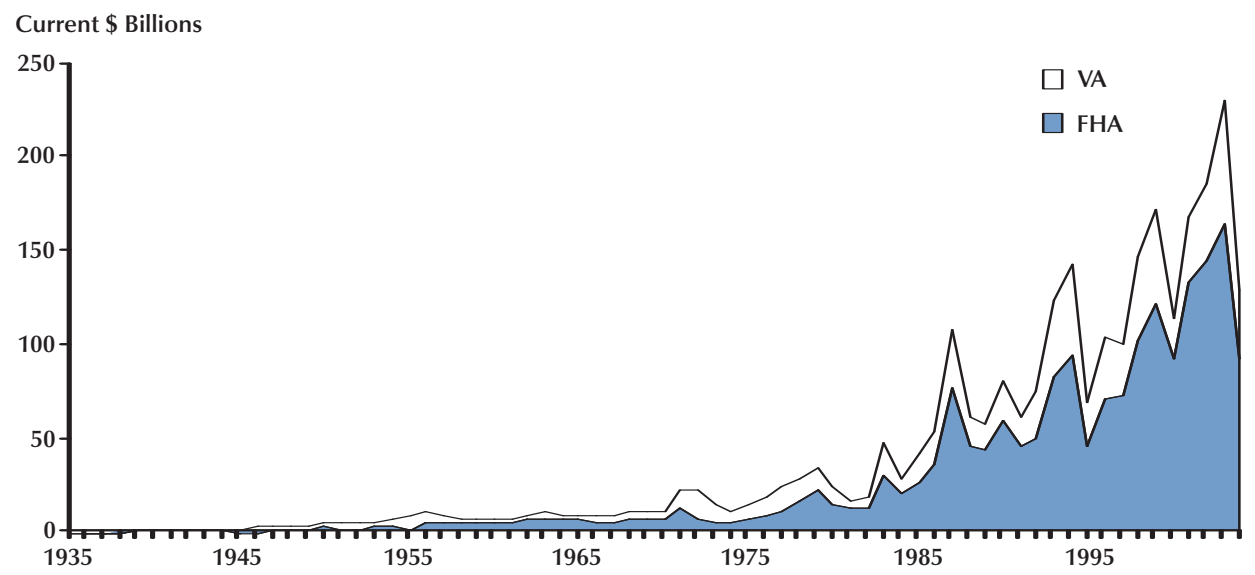

SOURCE: U.S. Census Bureau, Statistical Abstract of the U.S. (various years); National Association of Homebuilders (1986); www.fanniemae.com/ir/pdf/resources/housingmortgage.pdf; www.fanniemae.com/ir/pdf/resources/housingmortgage.pdf.

\section{Figure 3}

FHA and VA Shares of Total Originations, 1939-2004

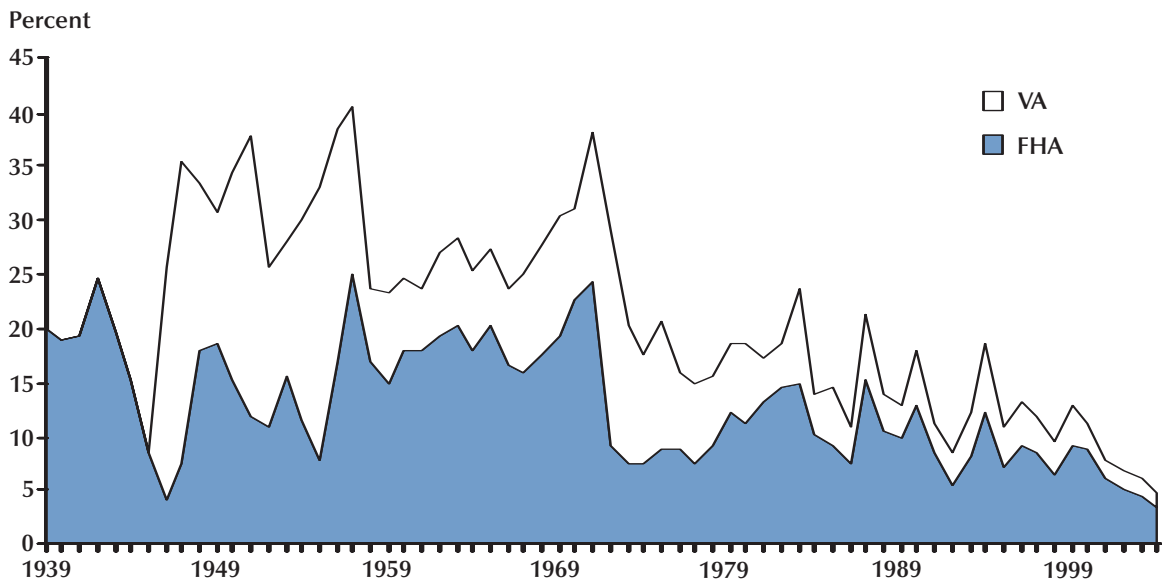

NOTE: Data for 1965-69 total originations are approximate.

SOURCE: U.S. Census Bureau, Statistical Abstract of the U.S. (various years); www.huduser.org/periodicals/ushmc/summer99/histdat5.html; www.fanniemae.com/ir/pdf/resources/housingmortgage.pdf. 


\section{Figure 4}

\section{FHA and VA Shares of All Insured Mortgages, 1980-99}

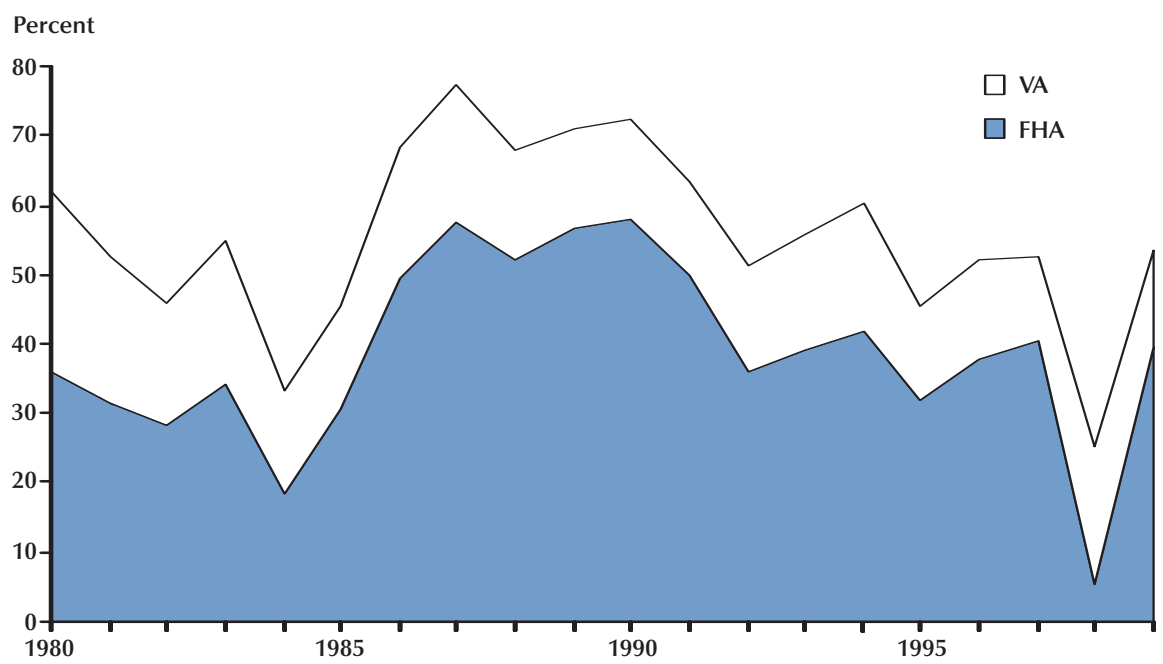

SOURCE: www.huduser.org/periodicals/ushmc/winter99/histdat4.html.

made private lenders more inclined to offer competitive liberal mortgage products.

Second, variations in policy-by statute or practice-affect the extent to which insured mortgages can "compete" with the private mortgage industry. Expansions in coverage shortly after World War II-higher LTVs and longer repayment terms-made FHA and VA mortgages more attractive to lower-income households. But, over time, fixed-dollar limitations on the loan amounts greatly reduced the role of the FHA and the VA in providing insurance to middle- and uppermiddle-income households. Figure 4 reports the number of FHA and VA mortgages as a fraction of all insured mortgages. As the figure shows, FHA and VA mortgages were almost 80 percent of all insured mortgages in 1987. This fraction declined by half through 1995 before increasing again when lending limits were liberalized. Figure 5 estimates, from the era of the Great Society to the present, the fraction of new single-family homes whose selling prices made them eligible for FHA mortgage insurance. As the figure indicates, limitations on the maximum loan amount reduced the potential coverage from about 90 percent of new homes completed in 1964 to about 15 percent of new homes completed three decades later. ${ }^{7}$ Systematic increases during the past decade in the maximum size of mortgages eligible for FHA financing has increased eligibility again, to as much as one-third of the new houses completed in $2004 .^{8}$

The trends reported in Figures 4 and 5 are the outcomes of policy decisions about the segments of the owner-occupied housing market in which the FHA has been authorized to offer mortgage insurance. Figure 6 shows analogous estimates of the fraction of new homes eligible for VA guarantees. Until 1988, the trend was quite similar. ${ }^{9}$

7 The estimates in Figure 5 are quite crude. The distribution of prices for new homes is reported in gross categories (but the distribution of prices for existing homes is not available at all). No adjustment is made for higher-cost FHA regions (for which higher limits were permitted beginning in 1994).

8 In 1994, the FHA loan limit was increased from a fixed amount to a fraction of the limit imposed on GSE purchases of mortgages (the "conforming limit"). As noted below, this limit is revised annually on the basis of average home prices. The FHA loan limit was set at 38 percent of the GSE limit and 75 percent of the GSE limit in high-cost metropolitan areas. In 1998, these limits were further liberalized to 47 percent and 87 percent, respectively.

9 In 1988, the VA eligibility limit was extended from houses valued at 1.67 times the maximum guarantee to houses valued at 4 times the maximum guarantee. This immediately made many more highvalued homes eligible for federal guarantees. 
Quigley

Figure 5

Estimated Percent of New Single-Family Homes Eligible for FHA Insurance, 1964-2004

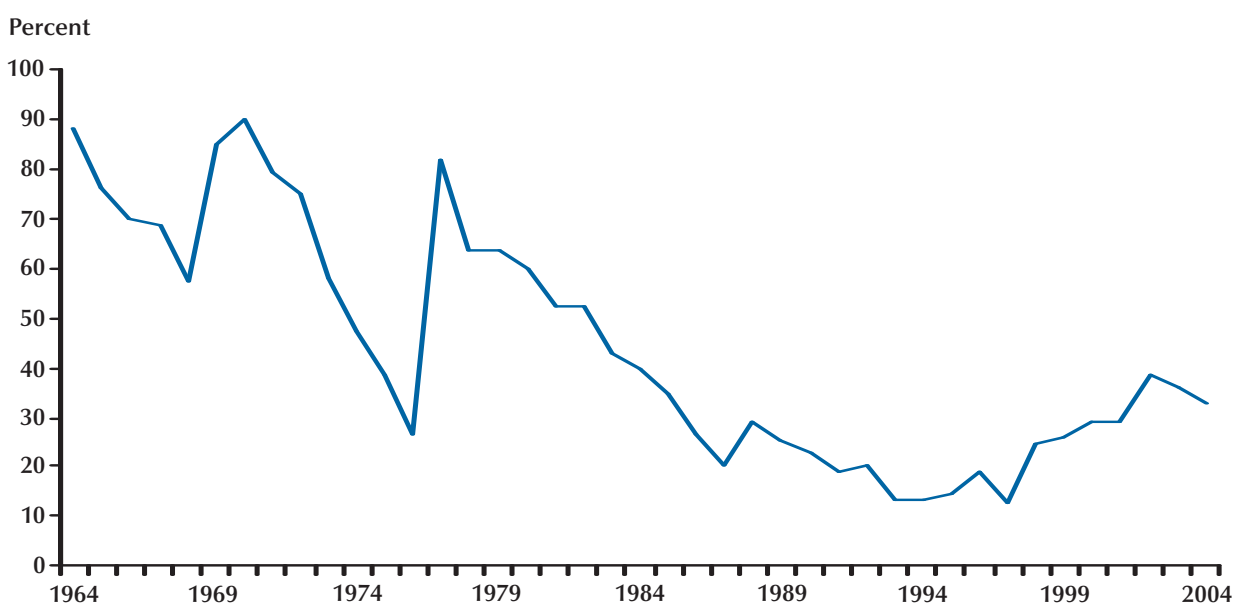

NOTE: Reported figures are underestimated after 1993.

SOURCE: Vandell (1995); U.S. Census Bureau, Construction Statistics Series C25 (various years).

Figure 6

Estimated Percent of New Single-Family Homes Eligible for VA Insurance, 1964-2004

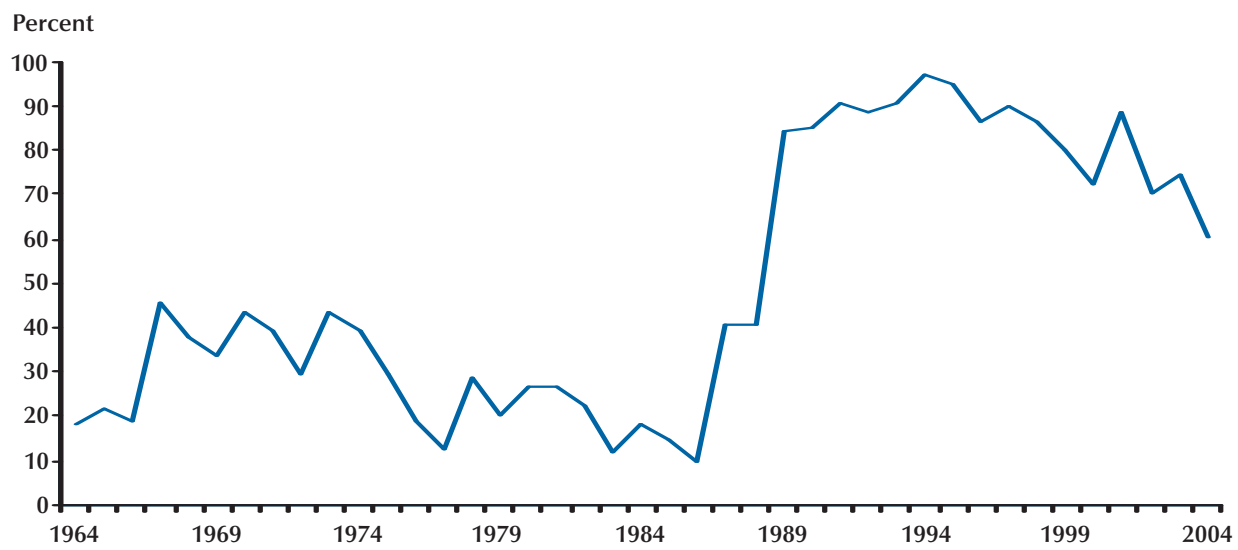

SOURCE: U.S. Census Bureau, Construction Statistics Series C25 (various years). 


\section{Figure 7}

\section{FHA-Insured Mortgage Debt Outstanding, 1949-2003}

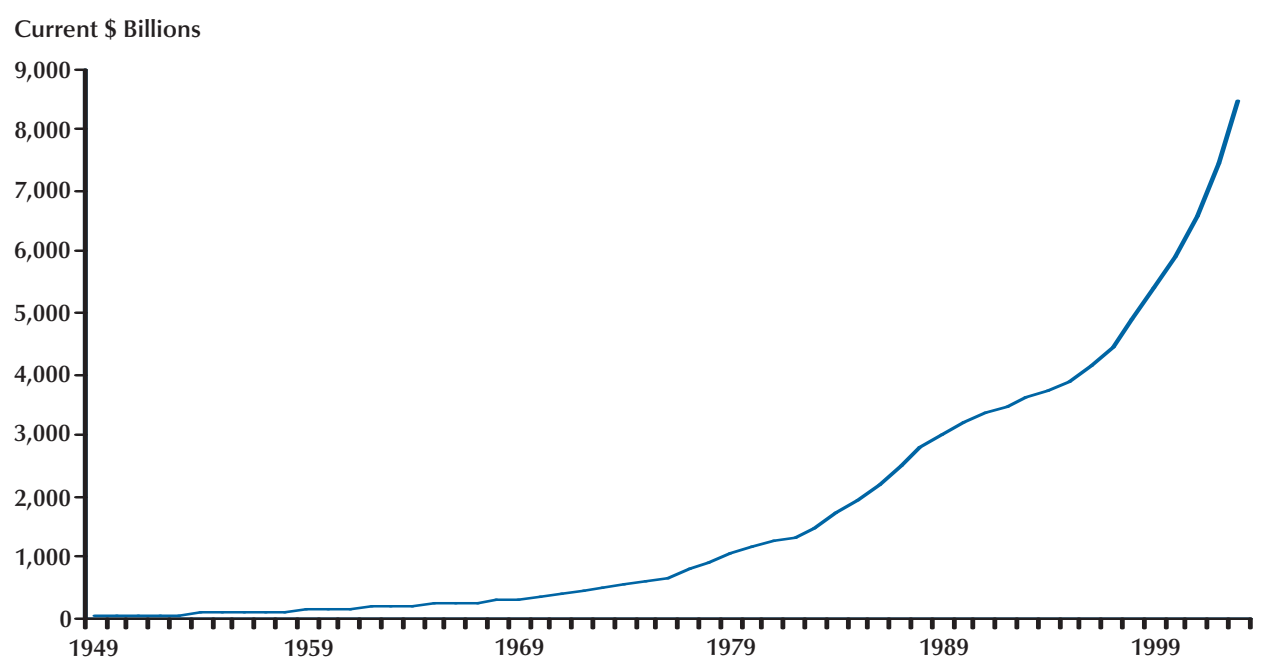

SOURCE: Council of Economic Advisors, Economic Report of the President (various years, Table B-76).

The rules governing coverage affect the "market share" of government-insured mortgages in total originations. Because it was demonstrated that liberal mortgage terms could be privately profitable, the eligibility of mortgages for federal insurance, especially mortgages for the high-valued properties demanded by high-income buyers, could be reduced. In this way, a reduced "market share" of guaranteed mortgages is evidence of the success and increased targeting of these programs. To be sure, national house-value limits for FHA and VA coverage are reflected in the market share of federally insured properties in various markets. Until 1994, a much smaller fraction of originations in high-priced housing markets, especially Western and Coastal housing markets, were eligible for FHA insurance. As noted below (see Figures 9 to 11), currently about 15 percent of newly issued mortgages are federally insured.

Despite these relative declines in the importance of the FHA in new originations, the volume of FHA debt outstanding has continued to rise steadily. Figure 7 reports the long-term trend. Note that FHA debt outstanding has increased from under $\$ 30$ billion in 1985 to about $\$ 440$ billion in 2003, a real increase of about 140 percent.
The mission of the FHA was expanded to include multi-family housing shortly after it was established. The National Housing Act of 1938 included provisions for a separate insurance program for multi-family housing for middle-income households. A separate reserve fund, the General Insurance Fund, was created, and it was envisioned that the General Insurance Fund would also be actuarially sound. But it was not until the 1960s that FHA multi-family housing programs became significant in size and scale.

A series of Great Society housing programs relied for the first time on privately owned multifamily housing to provide subsidized rental accommodation. Other programs subsidized homeownership directly. ${ }^{10}$ These programs combined subsidized interest rate mortgages, lower underwriting standards, and government insurance provided by the FHA. ${ }^{11}$ The volatile

10 Aficionados of U.S. housing policy may recall the "colorful" program titles: Section 221(d)(3), Section 235, and Section 236, to name the most notorious.

${ }^{11}$ Beyond these specific programs, the National Housing Act of 1968 directed the FHA, more generally, to lower underwriting standards in declining metropolitan areas. 


\section{Quigley}

\section{Figure 8}

\section{Multi-family and Commercial Share of FHA and VA Portfolio, 1949-2003}

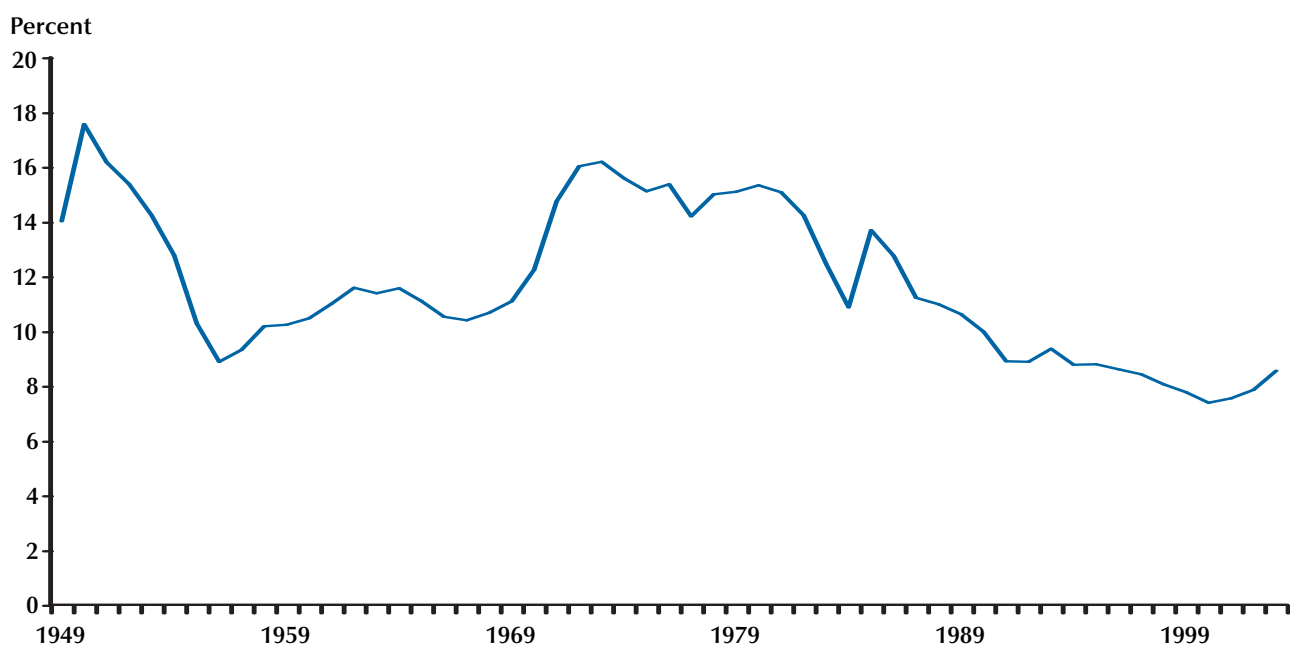

SOURCE: Council of Economic Advisors, Economic Report of the President (various years, Table B-75 ).

combination of liberal underwriting standards and loss insurance was enough to cause "smoke and fire," and additional allegations of inefficiency and corruption drew further attention to the "problems" of the FHA. ${ }^{12}$ It should be noted, however, that even in the absence of waste, fraud, or corruption, the design of these programs made the insurance provided by the FHA very expensive to U.S. taxpayers.

Two decades later, in the late 1980s, many of the successful FHA-insured subsidized multifamily projects reached the end of their compliance terms without the prospect of new subsidized financing and after the Tax Reform Act of 1986 had greatly reduced the returns to the syndication of apartments in the private-rental market. With long-lived capital, initial mistakes can be manifest for a long time. The General Insurance Fund and other reserve funds for the FHA multi-family housing programs have repeatedly required legislative appropriations to remain solvent.

Although these problems with the multi-family housing component of the FHA subsidized portfolio have been widely reported, it should be noted

12 These issues are discussed in detail by Vandell (1995). that lending for multi-family housing has never been a large fraction of the FHA portfolio, and its relative importance has systematically declined. As noted in Figure 8, multi-family housing insurance as a fraction of guaranteed and insured mortgages declined from about 15 percent in 1970 to less than 8 percent at the turn of this century.

In contrast, the mortgage insurance fund for the FHA single-family housing insurance program has remained solvent continuously and, with the exception of a few brief intervals, the fund has remained actuarially sound as well. Premium variations with LTVs have introduced some element of risk-based pricing, and variations in eligibility limits have kept enough low-risk borrowers in the pool.

For eligible households, the down-payment requirements and underwriting standards employed by the FHA have proven to be attractive when compared with the terms offered by conventional lenders. The Housing and Community Development Act of 1981 established explicit targets for serving low-income borrowers. These goals facilitated a lending environment in which the overwhelming fraction of FHA borrowers 


\section{Figure 9}

\section{FHA and VA Market Share of Originations by Borrower's Race, 1997-2003}

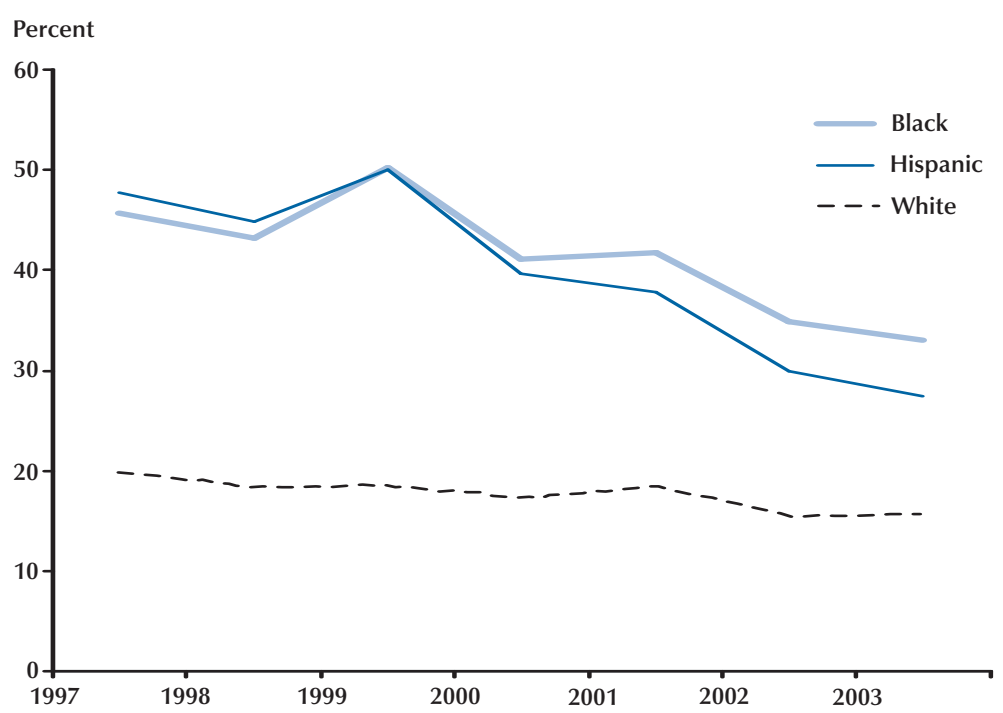

SOURCE: www.ffiec.gov/hmda/online_rpts.htm.

obtained mortgages with LTVs of 95 to 98 percent or more (as compared with 80 to 90 percent for conventional loans). FHA underwriting standards led to the acceptance of borrowers with "nontraditional" credit histories or with imperfect records. The diffusion of methods of credit scoring of borrowers makes it possible to compare the credit worthiness of FHA borrowers with those served by the conventional mortgage market. The availability of low-down-payment FHA mortgages and FHA mortgages for those with less-thanperfect credit scores has meant that the FHA market share of originations has been larger for those traditionally disadvantaged in the homeownership market. Figure 9 presents estimates of the number of FHA and VA mortgage originations in metropolitan areas as a fraction of all originations separately by race. ${ }^{13}$

As reported in the figure, in 1997 the FHA and VA had about a 20 percent share of mortgages issued to white borrowers. For black and hispanic

${ }^{13}$ These estimates are based on data reported under the Home Mortgage Disclosure Act, not data reported by the FHA. borrowers, the market shares were 46 percent and 48 percent, respectively. By 2003, the FHA and VA market share for all borrowers had declined. For whites it declined to about 16 percent. For black and hispanic borrowers, it declined to 33 percent and 27 percent, respectively.

Figure 10 reports the FHA and VA market share by the income of the census tract in which the borrower resides. In 1997, they had a 16 percent share of mortgages in upper-income neighborhoods and a 35 percent share of originations in low- and moderate-income neighborhoods. By 2003, the FHA and VA originated 8 percent of mortgages in upper-income neighborhoods and about twice that fraction in low- and moderateincome neighborhoods.

Figure 11 reports analogous FHA and VA market-share information by the fraction of minorities living in the census tract of origination. Here, market shares converged more rapidly during the 1997-2003 period.

Ambrose and Pennington-Cross (2000) have analyzed the market share of FHA mortgages across metropolitan regions in the United States. 
Quigley

Figure 10

FHA and VA Market Share by Census-Tract Income, 1997-2003

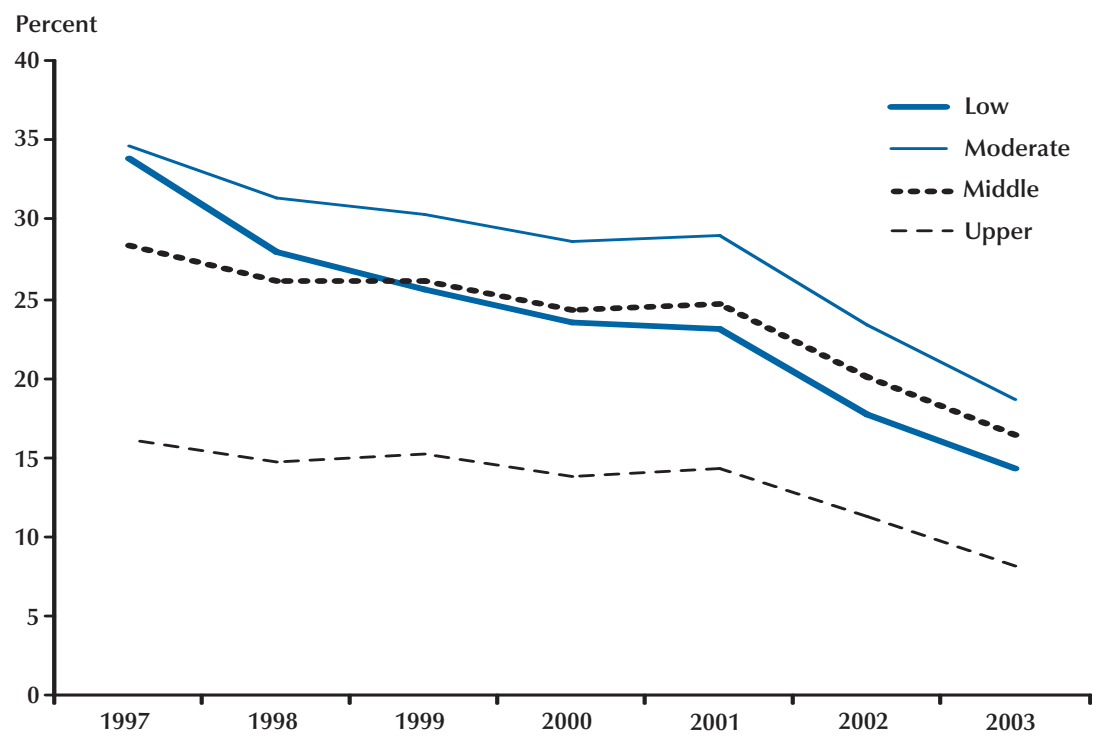

SOURCE: www.ffiec.gov/hmda/online_rpts.htm.

\section{Figure 11}

FHA and VA Market Share of Originations by Minority Population as a Percent of the Census Tract, 1997-2003

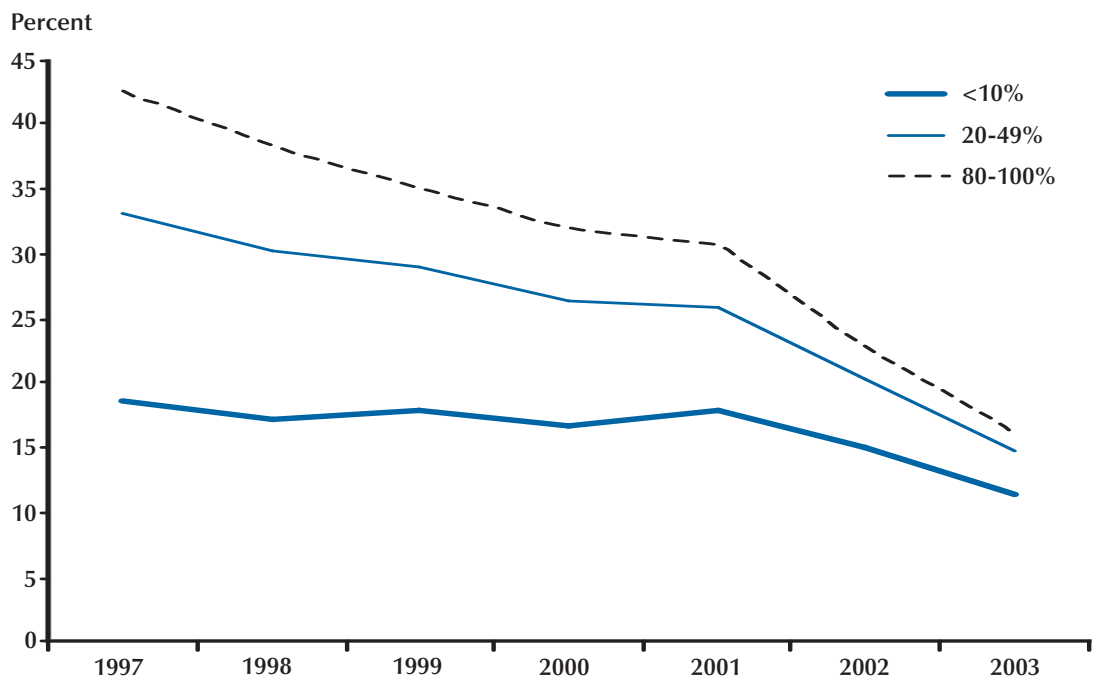




\section{Table 1} Distribution of New FHA and VA Mortgages by Borrower Race, Income, and Neighborhood,
1997-2003

\begin{tabular}{|c|c|c|c|c|c|c|c|}
\hline & 1997 & 1998 & 1999 & 2000 & 2001 & 2002 & 2003 \\
\hline \multicolumn{8}{|l|}{ Race } \\
\hline White & 67 & 67 & 58 & 63 & 65 & 64 & 65 \\
\hline Black & 13 & 13 & 16 & 14 & 13 & 13 & 13 \\
\hline Hispanic & 14 & 14 & 18 & 17 & 17 & 17 & 17 \\
\hline Other & 6 & 6 & 7 & 6 & 6 & 6 & 5 \\
\hline \multicolumn{8}{|l|}{ Income } \\
\hline Low to moderate & 43 & 45 & 46 & 45 & 47 & 50 & 50 \\
\hline Middle & 36 & 35 & 35 & 35 & 34 & 32 & 32 \\
\hline Upper & 20 & 20 & 19 & 20 & 19 & 18 & 17 \\
\hline \multicolumn{8}{|c|}{ Percentage of Minorities in Census Tract } \\
\hline$<10$ & 39 & 39 & 39 & 39 & 41 & 41 & 25 \\
\hline $10-49$ & 48 & 48 & 48 & 48 & 47 & 47 & 55 \\
\hline $50-79$ & 8 & 8 & 8 & 8 & 7 & 7 & 12 \\
\hline$\geq 80$ & 6 & 5 & 5 & 5 & 5 & 5 & 8 \\
\hline
\end{tabular}

Their analysis suggests that FHA activity is higher in cities and metropolitan areas where economic risks are higher and where the probability of recession is greater. When conventional underwriters reduce lending in local markets, the FHA takes up some of the slack. (See also Ambrose, PenningtonCross, and Yeazer, 2002.)

Table 1 reports the distribution of FHA and VA new business from 1997 to 2003 along the same three dimensions used in Figures 9 to 11. Although the market share of white borrowers is less than 20 percent, about two-thirds of new mortgages are made to white borrowers. Since 1997 , there has been a small increase in the fraction of mortgage originations to minority borrowers and a decline, from 67 percent to 65 percent, in the fraction of white borrowers. There has been a larger increase in the fraction of new mortgage originations in low- and moderate-income census tracts, from 43 percent to 50 percent, and a substantial decline, from 39 to 25 percent, in the fraction of mortgages originated in census tracts whose population was 90 percent or more non- hispanic white. Low- and moderate-income census tracts have experienced a larger increase in the portfolio of new mortgages, from 43 to 50 percent; and there has been an even more substantial increase in the fraction of FHA and VA mortgage originations in minority neighborhoods.

Given borrower characteristics, lower down payments, and looser underwriting standards, government-insured and -guaranteed mortgages are somewhat riskier than conventional loans. Figure 12 compares foreclosure rates on FHA, VA, and conventional mortgages over the past 30 years. Foreclosure rates on conventional mortgages were very low, increasing after 1981 to about 0.7 percent. In absolute terms, FHA foreclosure rates are low, but they also increased after 1981 and now average between 1 and 3 percent. These rates are about half again as high as the foreclosure rates on VA loans and two-and-one-half times as large as the foreclosure rates on conventional mortgages. There is a slightly increasing trend in foreclosure rates for all mortgages, and the trend is a bit higher for FHA loans. 


\section{Quigley}

\section{Figure 12}

\section{Mortgage Foreclosure Rates, 1961-2002}

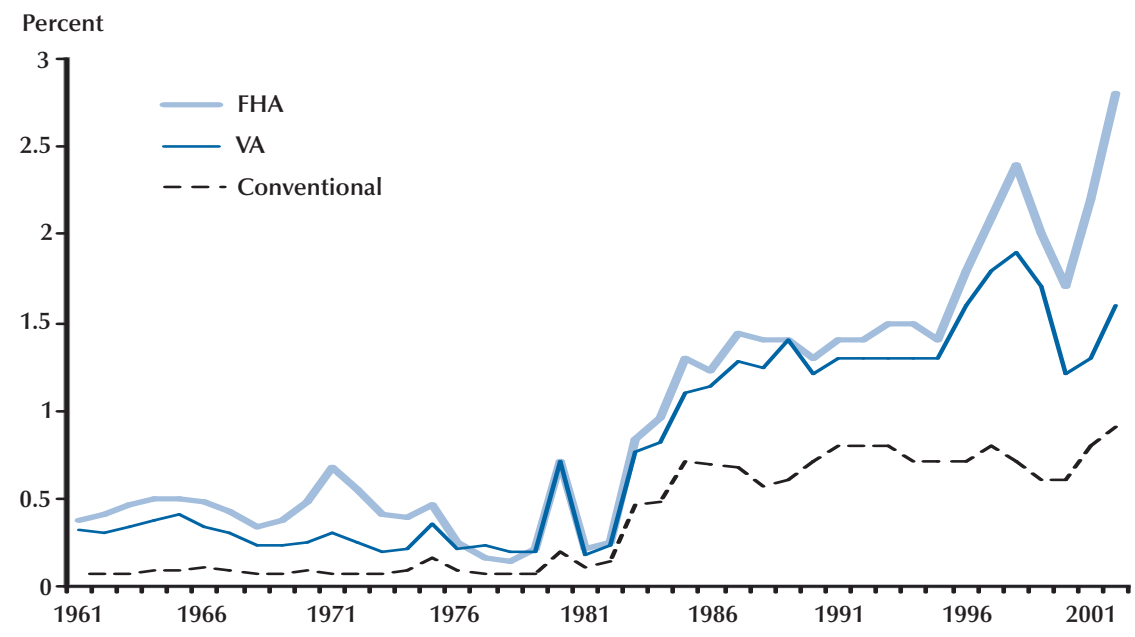

NOTE: Data for 1972 are approximate.

SOURCE: Mortgage Bankers of America, National Delinquency Reports (various years).

\section{ECONOMIC EFFECTS}

It seems clear that the institution of singlefamily housing insurance and guarantee programs played a leading role in developing the American mortgage market. After a half century, however, it is also clear that these institutions now play a less central role in expanding homeownership opportunities for U.S. households. There are, however, at least three salutary effects of this public intervention in the mortgage market.

First, these government agencies may be presumed to be less discriminatory than private actors in the mortgage market. Racial discrimination in homeownership markets has been well documented for three decades (e.g., Kain and Quigley, 1975, and Munnell et al., 1986). Although the precise mechanism underlying this discrimination is unclear, and actions may be based on statistical discrimination as well as simple prejudice (see, especially, Ross and Yinger, 2002), there is substantial and continuing discrimination against minority households in the market. Government action in providing insurance is but one tool to help rectify this inequity and to increase minority access to homeownership.

Figure 9 provides some indirect evidence on this point. The large FHA market share among African Americans and Hispanics reflects the number of these households who are eligible for the program. However, the large uptake of FHA mortgages among minority households also suggests that the institution serves minority borrowers and their lenders.

Second, the continuing demonstration provided by the looser terms for government mortgages may increase homeownership more generally among the eligible population. However, the accumulated experience of private mortgage insurance and the recent technical developments in quantifying potential default risk among borrowers suggest that the private sector may be quite capable of supplying credit at terms comparable to those provided by the FHA. Thus, the current programs provided by the FHA may increase homeownership among the eligible population, but the elimination of the FHA might simply induce private lenders to be more aggressive in this segment of the market. 
Third, those eligible homeowners who are "inframarginal" - that is, their homeownership probabilities are unaffected by the existence of the FHA - may be able to buy somewhat more expensive houses in better neighborhoods as a result of the program.

There is considerable research using a variety of national datasets analyzing the effects of the FHA on the homeownership rates of households. The most widely reported of these studies, government reports commissioned by HUD, ${ }^{14}$ conclude that a quite substantial number of U.S. households have become homeowners as a result of the FHA. These government-sponsored surveys examine samples of recent home purchasers, noting (i) those who purchased using conventional mortgages with private mortgage insurance, (ii) those veterans who would have been unable to purchase with private insurance but who were able purchase with a VA loan, and (iii) those who could not buy their home with private mortgage insurance or a VA loan but who could afford to buy it with an FHA loan. The studies suggest that the second category measures the effectiveness of the VA in stimulating homeownership and the third category measures the effectiveness of the FHA. But these methods clearly overestimate the effects of these institutions-because the private mortgage industry would certainly expand in these market segments in the absence of government programs. In addition, many households who barely qualify to purchase their homes under government programs would continue to qualify for homeownership by simply purchasing other, less expensive, houses in the absence of government programs.

Other studies have examined micro data sets to estimate the fraction of renters or potential house buyers who would qualify for home purchase under FHA qualification rules but not under conventional underwriting criteria. For example, Savage and Fronczek (1993) analyzed renters in the Survey of Income and Program Participation, concluding that the FHA adds only a narrow segment of the population to the pool of potential home buyers. Using micro data from the American

\footnotetext{
${ }^{14}$ See, for example, Bunce et al. (1995).
}

Housing Survey, Lafayette, Haurin, and Hendershott (1995) calibrated a model of tenure choice for young households and simulated the change in homeownership patterns if the down payment and income rules of the FHA were eliminated. Their results suggested that only a very small increase in homeownership rates among young adults could be attributed to the FHA.

Goodman and Nichols (1997) analyzed two waves each of data collected by the Panel Study of Income Dynamics and by the National Longitudinal Study of Youth, investigating the fraction who would qualify for an "FHA-only" mortgage at the beginning and the end of a five-year interval. The authors found that the overwhelming majority of those who qualified for FHA-only mortgages at the initial period qualified for a conventional mortgage at the end of the interval. From this they conclude that the effect of the FHA on homeownership is to accelerate ownership, not to increase homeownership. ${ }^{15}$ (Note John Weicher's elaboration on the significance of this finding in his commentary on this paper.)

Monroe (2001) analyzed the Public Use Micro Samples (PUMS) generated by the U.S. Census in 1970, 1980, and 1990 for metropolitan households. He exploited metropolitan variation in loan limits and temporal variation in underwriting standards to estimate the fraction of metropolitan dwellings that a given household in the PUMS could afford with an FHA loan but not with a conventional loan. He found that the temporal and spatial variation in this measure is significantly associated with homeownership. In particular, he found that the FHA increased homeownership by 0.6 percentage points, on average, during the 1970-90 period. Among those most affected by the FHA (i.e., those at the 90th percentile of the fraction), homeownership increased by 1.6 percentage points.

Significantly, the estimated effect of the FHA on the homeownership of black households was twice as large on average (1.4 percentage points at the mean) and more than twice as large among those most affected by the FHA (3.7 percentage points at the 90th percentile).

\footnotetext{
${ }^{15}$ This suggests that the FHA will become less effective in accelerating homeownership as the population ages. And it also suggests that the "acceleration" of homeownership may reduce the savings rate in the cohort of those contemplating a first-time home purchase.
} 


\section{Quigley}

\section{Figure 13}

\section{Schematic of MBS Industry}

\begin{tabular}{|c|c|c|c|}
\hline \multicolumn{3}{|c|}{ Agency MBS } & \multirow{2}{*}{ Private-label MBS } \\
\hline Ginnie Mae & Fannie Mae & Freddie Mac & \\
\hline $\begin{array}{l}\text { FHA- and VA-insured } \\
\text { mortgages }\end{array}$ & \multicolumn{3}{|c|}{ Privately insured mortgages } \\
\hline $\begin{array}{l}\text { Generally low-balance } \\
\text { mortgages }\end{array}$ & \multicolumn{2}{|c|}{$\begin{array}{l}\text { Mortgages conform to balance limits } \\
\text { and underwriting rules }\end{array}$} & $\begin{array}{l}\text { Mortgages do not conform } \\
\text { to balance limits and/or } \\
\text { underwriting rules }\end{array}$ \\
\hline $\begin{array}{l}\text { Explicit government } \\
\text { guarantee }\end{array}$ & \multicolumn{2}{|c|}{ Implicit government guarantee } & $\begin{array}{l}\text { Credit enhancement: } \\
\text { subordination, } \\
\text { overcollaterization }\end{array}$ \\
\hline \multicolumn{4}{|c|}{ Amount issued (2004 $\$$ billions) } \\
\hline$\$ 126$ & $\$ 527$ & $\$ 365$ & $\$ 865$ \\
\hline \multicolumn{4}{|c|}{ Amount issued (1995 \$ billions) } \\
\hline$\$ 72$ & $\$ 110$ & $\$ 86$ & $\$ 49$ \\
\hline
\end{tabular}

SOURCE: Inside $M B S$ and $A B S$.

\section{MORTGAGE CREDIT}

Federal support for housing credit also began in the aftermath of the Great Depression, with the establishment of the Federal Home Loan Bank (FHLB) System in 1932. FHLBs were chartered by Congress to provide short-term loans to institutions to help stabilize mortgage lending in local credit markets. These loans ("advances") were made to thrift institutions that specialized in retail mortgage finance. Interest rates on advances were determined by the low rates at which the FHLB System Board could borrow in the credit market. In 1938, the Federal National Mortgage Association (FNMA) was established as a wholly owned government corporation to facilitate a secondary market for the newly established FHA mortgage program. The willingness of the FNMA to buy these mortgages encouraged lenders to make FHA and, later, VA loans (see Haar, 1960, for a historical discussion).

In 1968, the Association was reconstituted as a GSE, Fannie Mae. Much of its portfolio of government-insured mortgages was transferred to the newly established Ginnie Mae, and its common stock was sold and publicly traded. ${ }^{16}$ The newly constituted Fannie Mae continued the practice of issuing debt to buy and hold mortgages, but expanded its operations to include the purchase of conventional mortgages not guaranteed or insured by the federal government.

Freddie Mac was established as a GSE in 1970. Freddie Mac was originally organized to buy mortgages originated by thrift institutions, and its shares were owned by FHLBs. Freddie Mac did not become a publicly traded firm until 1989. Originally, Freddie Mac chose not to hold purchased mortgages in its portfolio. Instead, mortgages were pooled and interests in those pools, mortgage-backed securities (MBS), were sold to investors, with the default risk guaranteed by Freddie Mac. ${ }^{17}$

Figure 13 is a schematic of the structure of the secondary mortgage market as it has evolved.

\footnotetext{
${ }^{16}$ The reorganization was, in large part, a response to changes in government accounting conventions that would otherwise have recorded net additions to the FNMA portfolio as federal expenditures (see Aaron, 1972).

${ }^{17}$ This structure is essentially identical to that which had been adopted by Ginnie Mae in their pass-through securities. Ginnie Mae securities, however, bore an explicit credit guarantee by the federal government.
} 
Mortgages insured by the FHA or guaranteed by the VA are securitized and guaranteed by Ginnie Mae. These securities are guaranteed by the full faith and credit of the U.S. government. Other mortgages, subject to specific balance ("conforming”) limits ${ }^{18}$ and underwriting guidelines, are securitized by Freddie Mac and Fannie Mae. These MBS are guaranteed against default risk by the GSEs themselves. Other mortgages, which do not conform to the balance limits or underwriting guidelines imposed by Fannie and Freddie, are routinely securitized by other private entities. These "private label” MBS may be insulated from default risk through overcollaterization, subordination, or other forms of credit enhancement.

Private-label MBS are standard finance products in which credit risk may be allocated among different tranches of a security, allowing final investors to tailor their holdings to their risk preferences.

The principal government subsidy provided to the GSEs arises because the debt instruments issued by them and the MBS guaranteed by them are perceived to be more secure than those issued by comparable institutions that do not operate under a federal charter. ${ }^{19}$ Although debt and securities issued by the GSEs clearly state otherwise, investors view the guarantees made by the GSEs as if they were made by the federal government itself. Some fraction of this benefit is passed through by the GSEs to mortgage borrowers, in the case of Fannie Mae and Freddie Mac, and to borrowers of FHLB institutions (mostly mortgage borrowers as well, but also to other clients of these institutions). The residual fraction of this benefit is retained by the shareholders of the GSEs. This residual arises from the GSEs competitive advantage, conferred by their federal charter, over other financial institutions that operate without such a charter.

\footnotetext{
${ }^{18}$ The "conforming loan limit," the maximum size of a mortgage loan that can be purchased or guaranteed by Fannie Mae and Freddie Mac, changes annually. It is indexed to the national average home price as estimated by the Federal Housing Finance Board. The 2005 limit is $\$ 359,650$.

${ }^{19}$ The GSEs benefit from several other subsidies as well. For example, they are exempt from state and local taxation and from certain Securities and Exchange Commission filing requirements as well. See Frame and White (2005) for a discussion and Congressional Budget Office (2001) for an estimate of their magnitude.
}

The size and growth of Fannie Mae and Freddie Mac are indicated in Figures 14 through 17. Between 1975 and 2000 the total assets of Fannie Mae increased 21-fold and the total assets of Freddie Mac grew 78-fold. As noted in Figure 14, during the past decade alone, Fannie Mae increased its assets by 365 percent and Freddie Mac by 650 percent.

The principal lines of business of these firms, the issuance of MBS and the investment in whole mortgages, increased commensurately. As indicated in Figure 15, during 1993-2003, the volume of outstanding MBS issued by Fannie Mae almost tripled to $\$ 1.3$ trillion, while the volume of outstanding MBS issued by Freddie Mac almost doubled to over $\$ 750$ billion.

Figure 16 reports the retained portfolios of Fannie Mae and Freddie Mac. These portfolios consist of a mixture of whole loans, individual mortgages, and MBS which are owned by these firms and retained for investment purposes. These portfolios are large, and they have grown quite rapidly in the recent past. Between 1997 and 2003, the retained portfolios of the GSEs have tripled in size. As indicated in Figure 17, Fannie Mae’s debt outstanding in 2003 was $\$ 962$ billion, up from $\$ 201$ billion a decade before. Freddie Mac's debt outstanding in 2004 was $\$ 732$ billion, up from $\$ 93$ billion a decade before. These are very large firms that have grown rapidly, especially in the past decade.

Just as the FHA shaped the primary mortgage market in the United States, so the rapid growth of the GSEs beginning in the 1970s led to fundamental changes in the secondary mortgage market. Until the 1970s, U.S. mortgage finance hardly differed from the caricature of the James Stewart movie of 1946. Banks and thrift institutions mobilized savings and originated mortgages, which were then kept as assets in their portfolios. After origination, these same institutions serviced the mortgages, collecting payments and guarding against delinquencies. Indeed, despite the growth of national pension funds and institutionalized investors, Weicher (1994) reported that this localized structure characterized some 60 percent of the mortgage market as late as 1968. 


\section{Quigley}

\section{Figure 14}

Freddie Mac and Fannie Mae Total Assets, 1986-2003

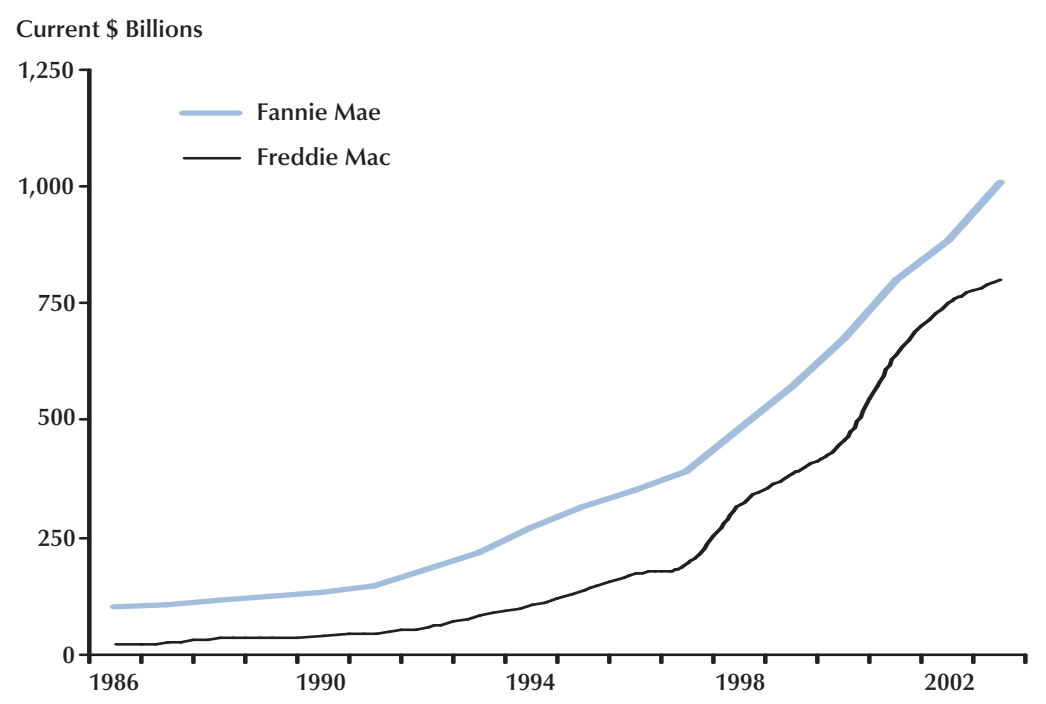

SOURCE: http://www.ofheo.gov/media/pdf/2005reporttocongress.pdf.

Figure 15

Freddie Mac and Fannie Mae Total MSB Outstanding, 1986-2003

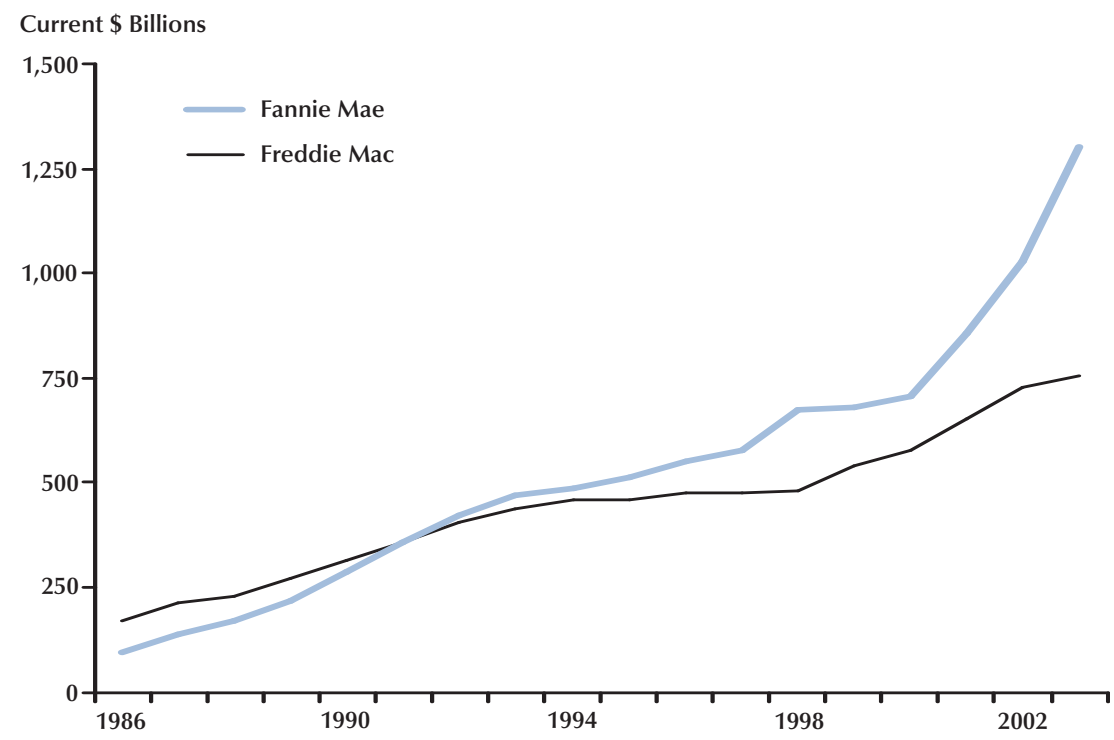

SOURCE: http://www.ofheo.gov/media/pdf/2005reporttocongress.pdf. 
Figure 16

Freddie Mac and Fannie Mae Total Retained Portfolios, 1986-2003

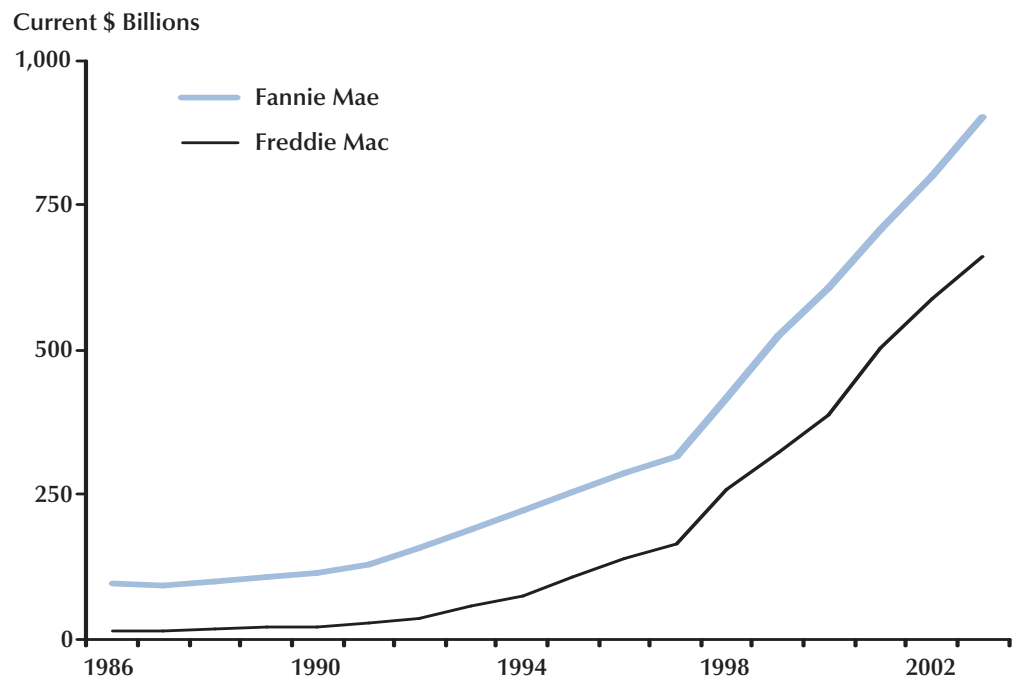

SOURCE: http://www.ofheo.gov/media/pdf/2005reporttocongress.pdf.

Figure 17

Freddie Mac and Fannie Mae Total Debt, 1986-2003

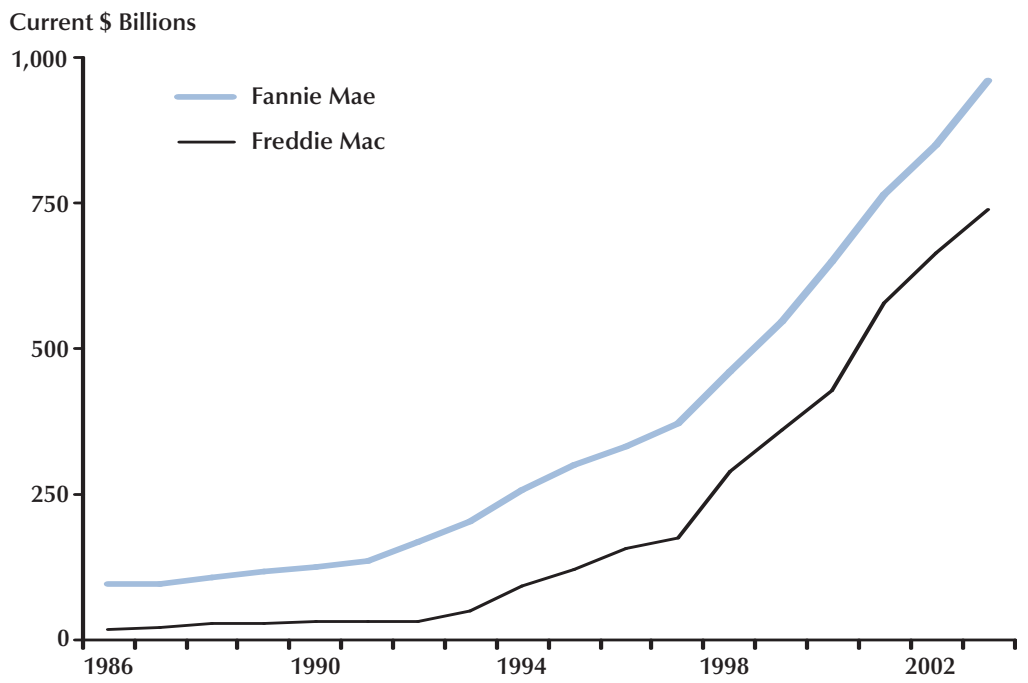

SOURCE: http://www.ofheo.gov/media/pdf/2005reporttocongress.pdf. 
The growth of the GSEs facilitated a completely decentralized process, with a variety of firms specializing in different aspects of the secondary market. Now, thrifts and mortgage banks originate mortgages, or independent mortgage brokers originate mortgages on behalf of banks. After origination, these firms sell the mortgages to Fannie Mae and Freddie Mac and sell the servicing rights to other specialized firms. Fannie and Freddie may hold the mortgages as investments or they may create MBS that are sold to individual investors, institutions, pension funds, or banks.

The two lines of business undertaken by the GSEs are represented in Figures 15 and 16. Both benefit directly from the subsidy provided by the implicit federal guarantee of creditworthiness. In the first line of business-the issuance of MBSthe GSEs buy mortgages from originators and issue MBS, which the agencies guarantee against default risk. Often, mortgage originators repurchase securities formed from the same mortgage pools they sell to Freddie Mac and Fannie Mae. ${ }^{20}$ Specifically, the GSEs sell off a "package": the cash flows from an underlying mortgage pool guaranteed against default, minus an annual fee charged on unpaid balances. Fannie Mae and Freddie Mac can sell this package at a lower price than other private firms because their guarantee is implicitly backed up by the full faith and credit of the federal government. As indicated in Figure 15, the total MBS outstanding in 2003 and guaranteed by Fannie Mae and Freddie Mac was $\$ 2,053,330,000$.

In the second line of business, the GSEs issue debt and use the proceeds to invest, mostly in mortgages or in MBS. The implicit guarantee enables the firms to pay lower rates on the debt they issue, increasing the profitability of their investment in a portfolio of mortgages. As indicated in Figure 16, the total retained portfolios of whole mortgages and MBS held by Fannie Mae and Freddie Mac in 2003 was \$1,562,411,000.

In principle, the subsidy provided by the implicit guarantee can be calculated. Fannie Mae and Freddie Mac issue debt in the same market in which other participants in the banking and

\footnotetext{
${ }^{20}$ In this way, the banks and thrifts benefit from the elimination of credit risk and from the lower capital requirements imposed on guaranteed MBS rather than on an equivalent balance of whole mortgages.
}

finance industry participate. The yield difference ("spread") between the debt of the GSEs and that of other firms can be applied to the newly issued GSE debt to compute the funding advantage in any year arising from the yield difference. Of course, it is not quite straightforward to apply this principle and to produce credible estimates. The relevant benchmark estimate (i.e., the appropriate sector and bond rating) is not without controversy, and a comparison with broad aggregate indices combines bonds containing a variety of embedded options. Pearce and Miller (2001), among others, reported comparisons of the GSEs and AA-rated financial firms, suggesting that the agencies enjoyed a 37-basis-point spread. More sophisticated comparisons by Nothaft, Pearce, and Stevanovic (2002) suggest that this spread is 27 basis points between the GSEs and AA-minusrated firms. A careful analysis of yields for GSE debt and the option-free debt issued by a selection of finance industry corporations, by Ambrose and Warga (2002), concludes that the GSEs enjoy a 25- to-29-basis-point spread over AA-rated bank bonds and a 37- to 46-basis-point spread over AA-rated firms. Table 2 provides a terse summary of available estimates. These estimates are in the range of the (41-basis-point) spread assumed by the Congressional Budget Office (CBO, 2001) in estimating the annual federal subsidy to the GSEs. This is similar to the (40-basis-point) estimated spread used by Passmore (2005) in a similar exercise. $^{21}$

Estimates of this funding advantage have been used by the CBO (2001) to calculate the net present value of the implicit subsidy embedded in GSE debt issued in any year. The subsidy estimates are large, about $\$ 5.5$ billion per year for Fannie Mae’s newly issued debt during 1998, 1999, and 2000 and about $\$ 4.3$ billion per year for Freddie Mac's newly issued debt during 1998, 1999, and 2000. ${ }^{22}$

\footnotetext{
${ }^{21}$ Many of these estimates have been scrutinized and criticized by the GSEs themselves, and there is still considerable controversy about the magnitudes of the appropriate GSE spread. See Blinder, Flannery, and Kmihachi (2004).

22 The aggregate annual subsidy, including tax and regulation subsidies, was estimated to be $\$ 10.6$ billion in 2000 for Fannie Mae and Freddie Mac (and $\$ 13.6$ billion with the subsidies to the FHLBs included) (CBO, 2001). For 2003, the subsidy to Freddie Mac and Fannie Mae arising from their federal charters was estimated to be $\$ 19.6$ billion (CBO, 2004).
} 


\section{Table 2}

\section{Estimates of GSE Funding Advantage}

\begin{tabular}{|c|c|c|c|}
\hline Author & Data & Comparison & $\begin{array}{l}\text { Spread in } \\
\text { basis points }\end{array}$ \\
\hline U.S. Department of the Treasury (1996) & Bloomberg & Agency vs. A financials & $53-55$ \\
\hline Ambrose and Warga (1996) & $\begin{array}{l}\text { Fixed Income } \\
\text { Research Program }\end{array}$ & $\begin{array}{l}\text { Fannie Mae vs. } \\
\text { AA financials } \\
\text { AA corporate } \\
\text { A financials } \\
\text { A corporate }\end{array}$ & $\begin{array}{l}37-46 \\
38-39 \\
56-72 \\
55-65\end{array}$ \\
\hline Freddie Mac (1996) & $\begin{array}{l}\text { Lehman Brothers } \\
\text { relative value }\end{array}$ & $\begin{array}{l}\text { Freddie Mac vs. } \\
\text { AA and A } \\
\text { AAA }\end{array}$ & $\begin{array}{l}39 \\
23\end{array}$ \\
\hline Toevs (2000) & $\begin{array}{l}\text { Lehman Brothers } \\
\text { bond indices }\end{array}$ & Fannie Mae vs. AA indices & 37 \\
\hline Pearce and Miller (2001) & Bloomberg & Agency vs. AA financials & 37 \\
\hline Ambrose and Warga (2002) & $\begin{array}{l}\text { Fixed Investment } \\
\text { Securities Database }\end{array}$ & $\begin{array}{l}\text { Fannie Mae and Freddie Mac vs. } \\
\text { AA banks }\end{array}$ & $25-29$ \\
\hline $\begin{array}{l}\text { Nothaft, Pearce, } \\
\text { and Stevanovic (2002) }\end{array}$ & $\begin{array}{l}\text { Fixed Investment } \\
\text { Securities Database }\end{array}$ & $\begin{array}{l}\text { Fannie Mae and Freddie Mac vs. } \\
\text { AA debentures } \\
\text { A debentures } \\
\text { AA medium-term notes } \\
\text { A medium-term notes }\end{array}$ & $\begin{array}{l}30 \\
45 \\
27 \\
34\end{array}$ \\
\hline $\begin{array}{l}\text { Passmore, Sherlund, } \\
\text { and Burgess (2005) }\end{array}$ & $\begin{array}{l}\text { Bloomberg and } \\
\text { Lehman Brothers }\end{array}$ & $\begin{array}{l}\text { Fannie Mae and Freddie Mac vs. } \\
\text { AAA \& AA financials: } \\
68 \text { firms } \\
44 \text { firms } \\
15 \text { firms }\end{array}$ & $\begin{array}{l}41 \\
38 \\
38\end{array}$ \\
\hline
\end{tabular}

SOURCE: Nothaft, Pearce, and Stevanovic (2002); Ambrose and Warga (2002); and Passmore, Sherlund, and Burgess (2005).

Passmore (2005) extended the CBO reasoning, after deriving more precise estimates of spreads, to approximate the capitalized value of all currently outstanding debt issued by the GSEs. He concluded that the gross value of the subsidy is $\$ 122$ to $\$ 182$ billion. $^{23}$

\section{ECONOMIC EFFECTS}

The economic effects of the GSEs can be divided into two components: those that are reflected in the housing and mortgage market and within the firms and those that effect the broader

${ }^{23}$ Passmore's calculations also suggest that the net subsidy to the GSEs is $\$ 53$ to $\$ 106$ billion and that 44 to 89 percent of the GSEs' current market value is attributable to this subsidy. economy. Freddie Mac and Fannie Mae are large corporations, and as such their effects may be much broader than those affecting housing and home mortgage rates.

\section{Housing Market Effects}

The substantial subsidies arising from the competitive advantage of the GSEs means that mortgage rates for homeowners can be lower than they otherwise would be; that is, the subsidy can improve the lot of homeowners and home purchasers.

But, of course, in the first instance, the subsidy is provided to private profit-making firms with fiduciary duties to their shareholders. It is thus not obvious that all, or even most, of this public 
subsidy is passed through to homeowners. As documented by Hermalin and Jaffee (1996), the secondary market for mortgage securities (at least for those securities composed of loans conforming to the rules under which Fannie and Freddie operate) is hardly a textbook model of competition. The two GSEs are large, and each has a large market share of the conforming segment of the market. There are high barriers to entry, and the MBS product is more-or-less homogeneous. Moreover, mortgage originators have an inherent first-mover advantage in deciding which newly issued mortgages to sell to Fannie Mae and Freddie Mac. This may force the GSEs to pay a premium for the mortgages they purchase. These factors, imperfect competition and adverse selection, may mean that much of the subsidy accrues to the shareholders of the GSEs or to the owners of other financial institutions and not to homeowners.

In principle, the effects of the GSEs on mortgage rates can be calculated by computing and adjusting the spread between the interest rates on mortgages that conform to the loan limits and underwriting guidelines of the GSEs and the rates on other mortgages. As in the analysis of funding advantages, it is not quite straightforward to apply this principle and to produce credible estimates. (For example, most research compares the rates paid by borrowers with loans one dollar below the conforming limit with rates paid by borrowers with loans one dollar above the limit. But the latter group of borrowers differs from the former group, or else they surely would have made an additional one-dollar down payment and taken a conforming loan.)

Early analyses, e.g., by Hendershott and Shilling (1989), compare rates on jumbo and conforming mortgages and indicate that this spread was 24 to 39 basis points. More recent studies, e.g., Passmore, Sperks, and Ingpen (2002), McKenzie (2002), and CBO (2001), conclude that the spread is 18 to 23 basis points. These more recent studies differ mostly in their application of more-complex screens to ensure comparable data for conforming and nonconforming loans. Table 3, an extension of McKenzie (2002), summarizes these comparisons. More recent work by Passmore, Sherlund, and Burgess (2005) sug- gests that this spread may be as low as 16 basis points. ${ }^{24}$

Thus, it appears that the GSEs' funding advantage is about 30 to 40 basis points and the effect of this is to reduce mortgage rates by 16 to 25 basis points. Stated another way, a bit more than half of the subsidy rate to the GSEs is transmitted to homeowners in the form of reduced mortgage interest rates. Presumably, the remainder is transmitted to the shareholders of the enterprises or to the owners of other financial institutions.

In 1992, the Federal Housing Enterprises Financial Safety and Soundness Act established the regulatory structure of the GSEs and provided incentives for the GSEs to increase their services to lower-income households and neighborhoods. The legislation empowered HUD to set goals for "affordable housing," and HUD established three benchmark goals, which were ultimately finalized in December 1995.

The first goal (low-income housing) directs that a specified fraction of new loans purchased by the GSEs be originated by households with incomes below the area median. The second goal (underserved areas) requires that a specified fraction of mortgages be originated in census tracts with median incomes less than 90 percent of the area median, or else in census tracts with a minority population of at least 30 percent and with a tract median income of less than 120 percent of the area median income. The third goal (special affordable housing) targets mortgages originating in tracts with family incomes less than 60 percent of the area median, or else in tracts with incomes less than 80 percent of the area median and also located in specified low-income areas.

The goals originally set for 1996 were modest; for example, that 40 percent of the GSEs' mortgage purchases be loans to households with incomes below the area median. Over time, the HUD goals

\footnotetext{
${ }^{24}$ Of course, other reasons besides the greater liquidity provided by the GSEs could explain some of the spread between jumbo and conforming mortgages. Jumbo mortgages are generally prepaid more aggressively-borrowers have more at stake, if nothing else. This means that investors will require higher rates on jumbos merely to compensate. Borrowers with jumbo mortgages have better credit, and they make larger down payments. Thus the simple spread between jumbos and conforming mortgages, even if precisely measured, would exaggerate the effects of the GSEs in reducing interest rates. See, also, Ambrose, Buttimer, and Thibodeau (2001), Heuson, Passmore, and Sparks (2001), or Woodward (2004b).
} 


\section{Table 3}

\section{Estimates of Reduction in Mortgage Interest Rates Attributable to GSEs}

\begin{tabular}{lccc} 
Author & Time period & Region & $\begin{array}{c}\text { Reduction in } \\
\text { basis points }\end{array}$ \\
\hline Hendershott and Shilling (1989) & 1986 & California & $24-39$ \\
ICF Incorporated (1990) & 1987 & California & 26 \\
Cotterman and Pearce (1996) & $1989-93$ & California & $23-50$ \\
Pearce (2000) & & 11 States & $24-60$ \\
& $1992-99$ & California & 27 \\
Ambrose, Buttimer, and Thibodeau (2001) & & 11 States & 24 \\
Naranjo and Toevs (2002) & $1990-99$ & Dallas & $16-24$ \\
Passmore, Sparks, and Ingpen (2002) & $1986-98$ & U.S. & $8-43$ \\
CBO (2001) & $1992-99$ & California & $18-23$ \\
McKenzie (2002) & $1995-2000$ & U.S. & 23 \\
Ambrose, La Cour-Little, and Saunders (2004) & $1986-2000$ & U.S. & U.S. \\
Woodward (2004b) & $1996-2000$ & U.S. & 19 \\
Passmore, Sherlund, and Burgess (2005) & $1995-97$ & U.S. & 6 \\
Blinder, Flannery, and Lockhart (2006) & $1996-2001$ & U.S. & U.S. \\
\end{tabular}

SOURCE: McKenzie (2002); Ambrose, LaCour-Little, and Saunders (2004); Blinder, Flannery, and Lockhart (2006); Passmore, Sherlund, and Burgess (2005); and Woodward (2004b).

for new business have been increased; for example, 56 percent is the 2008 goal for the fraction of mortgage loans to lower-income households.

Figures 18, 19, and 20 summarize the three goals and the effectiveness of the GSEs in meeting these goals. $^{25}$

Presumably, the rationale for these three goals is to "demonstrate" the profitability of these kinds of mortgages and ultimately to increase the supply of mortgage credit to the borrower groups and neighborhoods targeted by the regulations. ${ }^{26}$ There is only minimal evidence on the effectiveness of this mandated GSE activity on mortgage

\footnotetext{
${ }^{25}$ In addition, beginning in 2005, HUD imposed specific numerical goals in these three areas for mortgages issued for new home purchases, excluding refinances.

${ }^{26}$ The demonstrations required to meet these mortgage purchase goals may require alternative mortgage products with different underwriting criteria and risk estimation. To the extent that these demonstrations are successful, they will increase liquidity to target borrowers and neighborhoods.
}

credit or housing outcomes. Evidence reported by Ambrose and Thibodeau (2004) relates only to geographically targeted lending (and is estimated from statistical analyses at the metropolitan level). This evidence provides very weak support for the effects of targeted GSE purchases on the availability of mortgage credit. Other work by Ambrose and Pennington-Cross (2000) concludes that GSE purchase rates are insensitive to local economic conditions. GSE activity does not help stabilize regional fluctuations. Detailed statistical analysis by Gyourko and Hu (2002) suggests that GSEs target low- and moderate-income borrowers who satisfy the GSEs' purchase goals but who reside in relatively higher-income tracts.

More recent research by Bostic and Gabriel (2005) analyzes census tract averages of GSE purchase activity and housing outcomes for census tracts with median incomes at the boundaries of those specified in the GSE housing goals and those specified in the 1977 Community Reinvestment 
Quigley

Figure 18

GSE Low- and Moderate-Income Housing Goal, 1996-2008: Percent of New Loans to Households Below Area Median Income

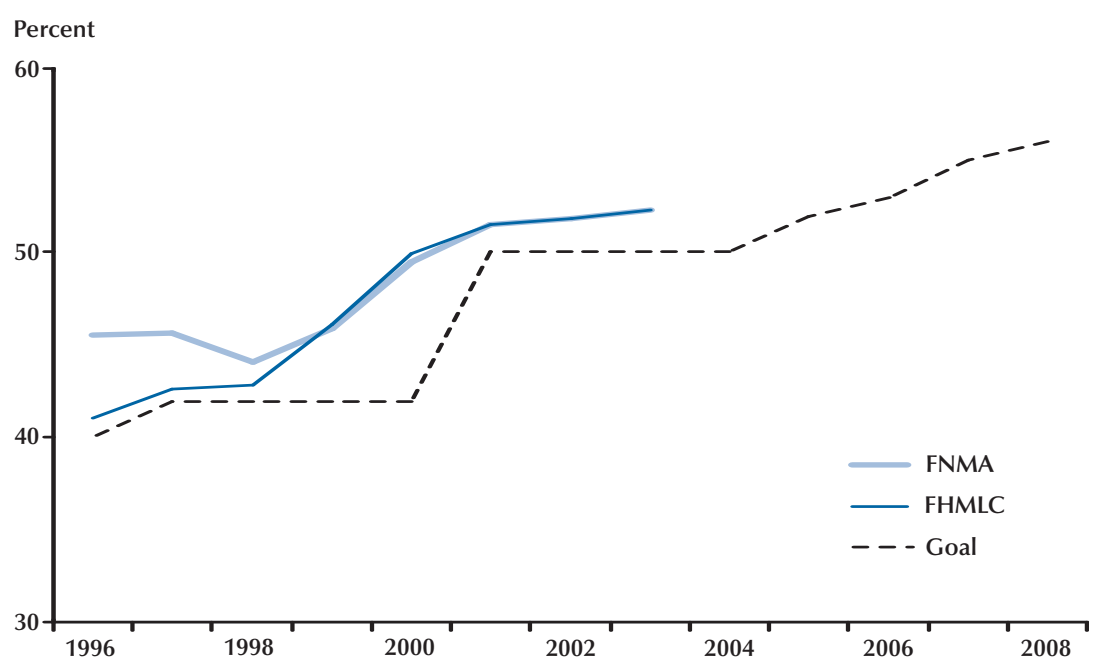

SOURCE: HUD Office of Policy Research and Development.

Figure 19

GSE Underserved-Area Housing Goal, 1996-2008: Percent of New Loans Credited Toward Goal

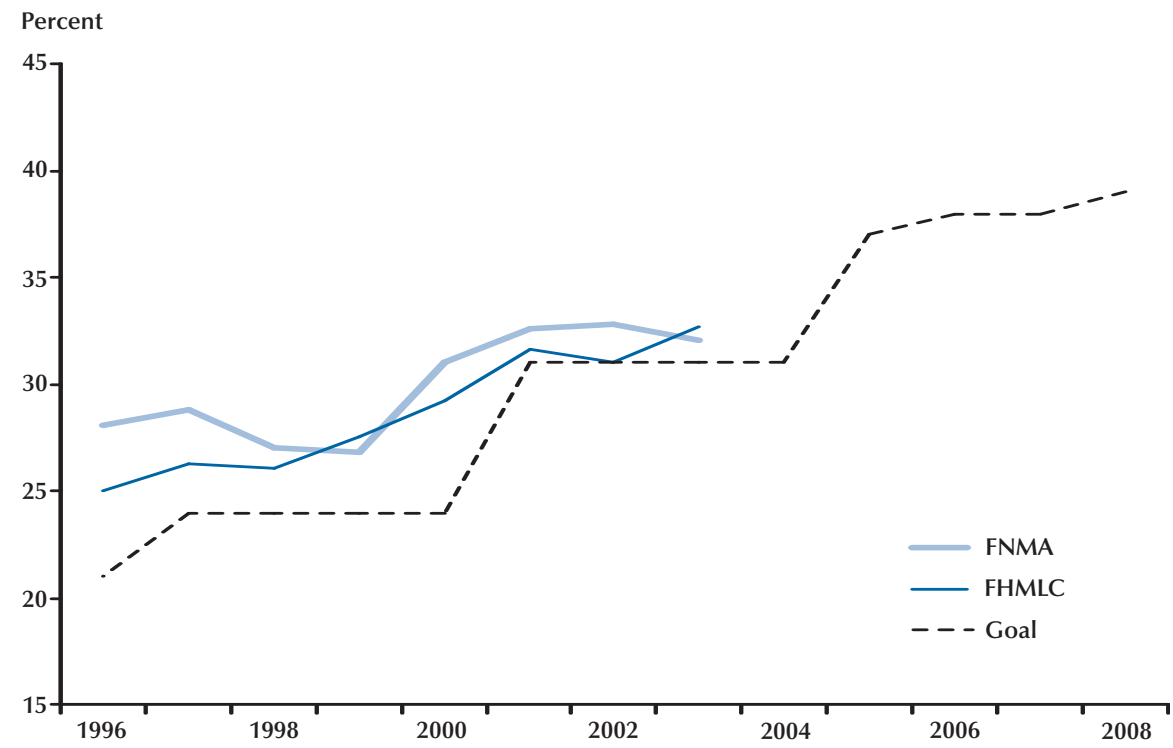

SOURCE: HUD Office of Policy Research and Development. 
Figure 20

\section{GSE Special Affordable Housing Goal, 1996-2008: Percent of New Loans Credited Toward Goal}

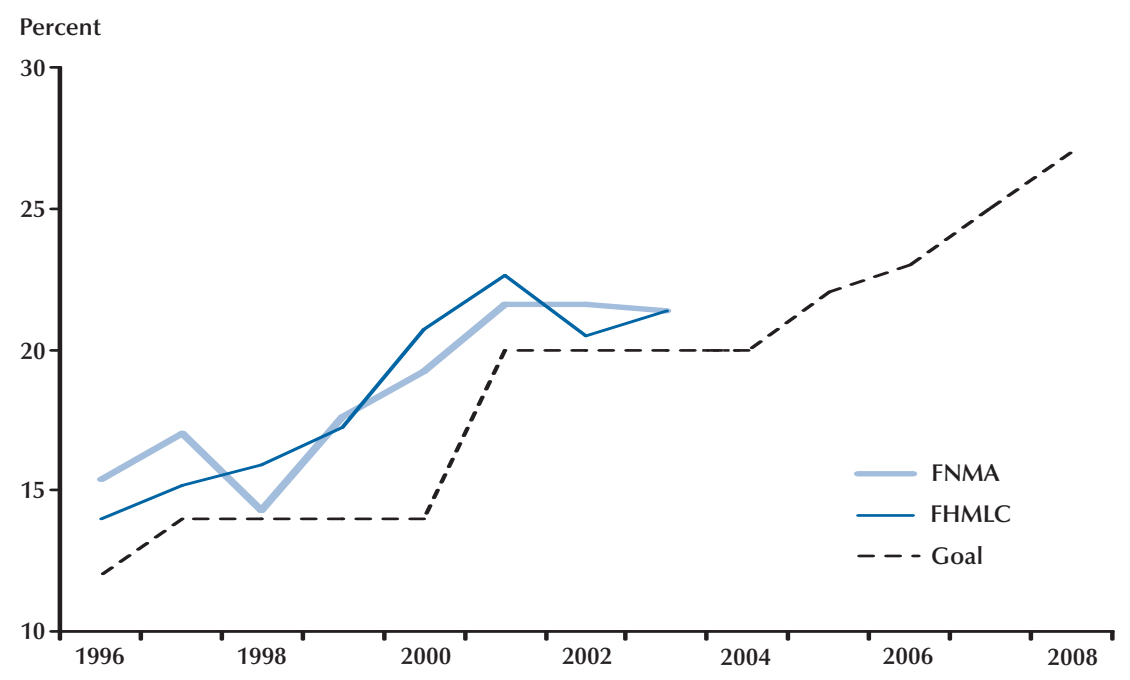

SOURCE: HUD Office of Policy Research and Development.

Act. An intensive analysis of California census tracts finds a positive association between GSE activity and housing market conditions, homeownership rates, and vacancies, but the association is generally not statistically meaningful. The authors conclude that "this research suggest[s] limited direct effects of GSE loan purchase activity on local housing markets.” Recent research by An, Bostic, and Deng (2006) suggests good reasons why this outcome might be anticipated. Their analysis is based on standard credit-rationing arguments. As the GSEs increase activity in selected neighborhoods to fulfill HUD mandates, they "cream" consumers with the best credit risks who then receive low-cost conventional mortgages instead of FHA loans. The FHA, which operates under a zero-profit constraint, is thus forced to increase its underwriting standards, thereby reducing credit availability to higher-risk borrowers. Using California data, An, Bostic, and Deng (2006) clearly show that increases in GSE lending activity in a census tract is associated with decreases in FHA activity. This is surely an area of research worthy of more attention.

\section{Broader Effects on the Economy}

The size and scale of the GSEs and their restricted lines of business provide the opportunity for them to stabilize residential mortgage markets and to cushion housing from the swings of monetary policy. This potential role was clearly recognized at the time the agencies were established (Aaron, 1972). To what extent can the GSEs offset the procyclical patterns of depository institutions in their holdings of residential mortgages? Increased stabilization of the housing sector could arise from the diversification opportunities provided by the MBS issued by the GSEs or by countercyclical patterns in the purchases of mortgages and MBS by the GSEs themselves. During recessions, MBS may be perceived to be sufficiently less risky than other investments, and this may reduce outflows of investment from the housing sector. The GSEs may also be more willing to act countercyclically than other actors in the capital market because of their "deeper pockets" (Peek and Wilcox, 2004).

There is some indirect evidence on this. Housing starts are no longer predicted by the 
indicia of mortgage credit availability but by Treasury rates and mortgage interest rates (McGarvey and Meador, 1991). Mortgage rates themselves have converged greatly over geographic regions (Rudolph and Griffith, 1997), and regional variations in residential investment have diminished (Browne, 2000).

Peek and Wilcox have provided some direct evidence on the stabilization issue, exploring whether the growth of secondary mortgage markets generally and GSE activities specifically have affected the cyclicality of mortgage flows (Peek and Wilcox, 2003) and the cyclicality of housing starts and residential investment (Peek and Wilcox, 2004). Their findings, based on vector autoregressions covering the period 1968-2001, do support the hypothesis that the MBS mortgage origination activities of the GSEs have reduced the procyclicality of housing. Their results also suggest that GSE activities in managing retained portfolios are much less important in mitigating cyclical shocks than are GSE activities in issuing MBS. Recent work by Lehnert, Passmore, and Sherlund (2005) suggests a limited scope for MBS and portfolio purchases in affecting primary mortgage markets. But Lehnert and his collaborators do find that the creation of MBS does reduce mortgage rates. ${ }^{27}$

Finally, Perli and Sack (2003) suggest that the mortgage-market hedging activities of the GSEs increase interest rate volatility and amplify movements in long-term interest rates.

\section{OBSERVATIONS}

The structure of the FHA and the GSEs is a classic example of the path-dependence of many economic activities. These institutions have played a leading role in the development of the primary and secondary mortgage markets and in defining the current structure of housing finance in the United States. Yet no one designing a

\footnotetext{
${ }^{27}$ More specifically, Lehnert, Passmore, and Sherlund (2005) find that large swings in GSE portfolio purchases do not affect interest rates. They also find that large swings in GSE-backed MBS issuance have very small effects on interest rates, but these effects are larger than the effects of portfolio purchases on interest rates.
}

housing-finance system anew would configure it much like the current system.

The economic case for creating a mortgage market before it existed was strong, and the results are impressive. But the economic case for subsidizing housing consumption is weak. It is now recognized that there are some externalities from homeownership, and the institutional arrangements surrounding the housing market do facilitate "forced" savings (Boehm and Schlottmann, 2002). Green and White (1997) analyzed three national data sets, finding significant effects of household homeownership in reducing teenage pregnancy and increasing high-school completion rates. DiPasquale and Glaeser (1999) found a strong linkage between homeownership and a variety of measures of "social capital." More recently, Haurin, Parcel, and Haurin (2002) found clear evidence of a link between homeownership and a variety of cognitive and behavioral outcomes for young children, suggesting that homeownership by younger adults increases the stock of human as well as social capital.

But no one suggests that there are external benefits to the amount of housing consumed. The FHA and the GSEs appear to have some small effects on homeownership, but most of their housing market effects are on quantities consumed.

The FHA may increase homeownership by a percent or so and may have stronger effects on minority homeownership rates. The operations of Fannie Mae and Freddie Mac may reduce mortgage interest rates by a quarter of a percent, and this in turn has some positive effect on homeownership. But most of the housing market effects are inframarginal, and much of the economic effects of the GSEs accrue to shareholders in the enterprises. It is currently possible to purchase a house valued at up to $\$ 170,000$ using an FHA loan, and the GSEs can buy and securitize mortgages on owner-occupied houses sold for up to about $\$ 350,000$. There is no conceivable externality that would justify public programs for the highincome purchasers of these dwellings. So, the first and perhaps the most practical policy prescription is to target these programs much more tightly.

Further increases in the goals set by HUD for the GSEs are one step in this direction. Increased 
targeting could also be promoted by lowering the conforming limits or, more realistically, by freezing the current limits for a good long time. But the best and simplest device to increase targeting would be simply to limit FHA and GSE mortgage activity to first-time home buyers. Less than onethird of home purchasers in any year are first-time buyers. ${ }^{28}$ These buyers tend to be younger and of lower incomes-precisely the group for whom the putative externalities to individuals and families are largest.

These changes would, over time, substantially reduce the magnitude of the federal presence in the mortgage market.

There seems little public rationale for the extensive portfolio holdings of the GSEs. As noted in Figure 16, portfolio investment has quite recently become a major line of business for Fannie Mae and Freddie Mac, and their private profits are facilitated by their federal charters. But there is little or no evidence that these investments stabilize cyclical swings in home purchases or reduce interest rates to home purchasers. These large portfolios have real costs. Because the agencies bear the interest rate risk as well as the credit risk for these portfolios, it is crucial that these investments be hedged in derivative markets and in the capital market more generally. As noted above, there is some evidence (Perli and Sack, 2003) that the dynamic hedging activities of the GSEs increase the volatility of long-term interest rates. (See Jaffee, 2003, for a detailed review of the hedging programs undertaken by Fannie and Freddie.) It is equally important that the Office of Federal Housing Enterprise Oversight regulators monitor these hedging activities closely so they can ensure the safety and soundness of the agencies. $^{29}$ This has high monitoring and transactions costs, and the risks of inadequate regulation are quite large. Without these extensive portfolios,

\footnotetext{
${ }^{28}$ Indeed, in 2000 it was estimated that 27 percent of the mortgages bought by the GSEs were originated by first-time homebuyers (see www.huduser.org/Datasets/GSE/Profiles19_00.pdf).

${ }^{29}$ Of course, Freddie Mac and Fannie Mae could adopt financial strategies to mitigate this interest rate risk completely, by issuing long-term callable notes to finance their portfolios of long-term mortgage assets (See Poole, 2005, for example). But, as noted by Woodward (2004a), the GSEs have incentives not to hedge their investments fully.
}

which serve basically private interests, these transactions costs and risks are eliminated. It would seem prudent to limit substantially the size of the retained mortgage portfolio managed by the GSEs. This could easily be achieved by the natural liquidation of some existing positions. (See Jaffee, 2005, for one specific suggestion.)

The finding that MBS issuance has about the same effect on primary mortgage market interest rates as retained portfolio purchases (Lehnert, Passmore, and Sherlund, 2005) also suggests that reducing retained portfolios and increasing the issuance of MBS would have no adverse effects on housing consumers.

Of course, the mortgages and MBS liquidated by the GSEs would show up in the portfolios of some other investors. But there are many banks, institutional investors, and hedge funds, and there are only two GSEs. Moreover, these other institutions also invest elsewhere in the economy, not narrowly in housing, and diversification across a broader number of investors and a broader spectrum of investor classes can only reduce portfolio risk.

As noted previously, it is estimated that 44 to 89 percent of the GSEs' current market value is attributable to the federal subsidy to these institutions (Passmore, 2005). By focusing GSE activities on first-time buyers over time and by liquidating large fractions of the GSEs' retained portfolios, slowly, the institutions could be reshaped without calamitous effects on share values in the short run.

Finally, there is the skunk in the middle of the road. The implicit federal guarantee that GSE assets are insured is an enormous contingent liability for the federal government. Frame and White (2005) estimate, by a "back of the envelope calculation," that the contingent liability is currently about $\$ 288$ billion. Lucas and McDonald (2005) use an options-based approach to estimate the insurance value of the implicit government guarantee to the GSEs. Their base-case calculation indicates a guarantee value of $\$ 7.9$ billion over a 10-year period. There are two ways to limit this public exposure. One is to repudiate the implied guarantee by some form of explicit non-guarantee. This would probably be hard to do politically, at 


\section{Quigley}

least in a convincing fashion. ${ }^{30}$ The alternative is to begin charging the GSEs for their disaster insurance, which currently is provided free and which they can sell profitably to investors. Of course, we do not know the right price for this disaster insurance and it would take a major effort to produce a credible estimate. ${ }^{31}$

But we certainly know that the right price for this service is not zero, and this provides a clear basis for a guarantee fee imposed by the taxpayers on loans insured by Fannie Mae and Freddie Mac.

\section{REFERENCES}

Aaron, Henry. Shelter and Subsidies: Who Benefits from Federal Housing Policies? Washington, DC: Brookings Institution, 1972.

Ambrose, Brent W.; Buttimer, Richard and Thibodeau, Thomas G. "A New Spin on the Jumbo/Conforming Loan Rate Differential.” Journal of Real Estate Finance and Economics, November 2001, 23(3), pp. 309-35.

Ambrose, Brent W.; LaCour-Little, Michael and Saunders, Anthony B. "The Effects of Conforming Loan Status on Mortgage Yield Spreads: A Loan Level Analysis." Real Estate Economics, Winter 2004, 32(4), pp. 541-69.

Ambrose, Brent W. and Pennington-Cross, Anthony. "Local Economic Risk Factors and the Primary and Secondary Mortgage Markets." Regional Science and Urban Economics, December 2000, 30(6), pp. 683-701.

Ambrose, Brent W.; Pennington-Cross, Anthony and Yeazer, Anthony. "Credit Rationing in the U.S. Mortgage Market: Evidence from Variation in FHA

\footnotetext{
${ }^{30}$ And if it were done in a convincing fashion, the GSEs would lose much of their market values overnight.

${ }^{31}$ In taking this proposal seriously, it is worth recalling the experience of Sallie Mae, the Student Loan Marketing Corporation, a GSE that was successfully privatized in an orderly manner between 1996 and 2004. The imperative for privatization arose in response to congressional imposition of an offset fee of 30 basis points per annum on all loans held or guaranteed by Sallie Mae. The guarantee fee provided enough of an incentive to make privatization more attractive than operation under a federal charter. (See Lea, 2005, for a highly illuminating exposition.)
}

Market Shares.” Journal of Urban Economics, March 2002, 51(2), pp. 272-94.

Ambrose, Brent W. and Thibodeau, Thomas G. "Have the GSE Affordable Housing Goals Increased the Supply of Mortgage Credit?" Regional Science and Urban Economics, May 2004, 34(2), pp. 263-73.

Ambrose, Brent W. and Warga, Arthur. "Implications of Privatization: The Costs to Fannie Mae and Freddie Mac," in Studies on Privatizing Fannie Mae and Freddie Mac. Washington, DC: U.S. Department of Housing and Urban Development, Office of Policy Development and Research, 1996.

Ambrose, Brent W. and Warga, Arthur. "Measuring Potential GSE Funding Advantages." Journal of Real Estate Finance and Economics, SeptemberDecember 2002, 25(2/3), pp. 129-50.

An, Xudong; Bostic, Raphael W. and Deng, Yongheng. "GSE Activity, FHA Feedback, and Implications for the Efficacy of the Affordable Housing Goals." Paper presented at the Annual Meeting of the Western Regional Science Association, Santa Fe, NM, February 2006.

Blinder, Alan S.; Flannery, Mark J. and Kmihachi, James D. "The Value of Housing Related GovernmentSponsored Enterprises: A Review of a Preliminary Draft Paper.” Fannie Mae Papers, III(2), 2004.

Blinder, Alan S.; Flannery, Mark J. and Lockhart, G. Brandon. "New Estimates of the Jumbo-Conforming Mortgage Spread." Unpublished paper, January 18, 2006.

Boehm, Thomas P. and Schlottmann, Alan M. "Housing and Wealth Accumulation," in Nicolas P. Retsinas and Eric S. Belsky, eds., Low Income Homeownership: Examining the Unexamined Goal. Washington, DC: Brookings Institution Press, 2002, pp. 407-26.

Bostic, Raphael W. and Gabriel, Stuart A. "Do the GSEs Matter to Low-Income Housing Markets?" Unpublished Paper, February 2005.

Browne, Lynn E. "National and Regional Housing Patterns." Federal Reserve Bank of Boston New England Economic Review, July-August 2000, pp. 31-57. 
Bunce, Harold L.; Capone, Charles A.; Neal, Sue G.; Reeder, William J.; Scheessele, Randall M. and Szymanoski, Edward. An Analysis of FHA's SingleFamily Insurance Program. Washington, DC: U.S. Department of Housing and Urban Development, Office of Policy Development and Research, October 1995.

Congressional Budget Office. Federal Subsidies and the Housing GSEs. Washington, DC: GPO, 2001.

Congressional Budget Office. Updated Estimates of the Subsidies to the Housing GSEs. Washington, DC: GPO, 2004.

Cotterman, Robert F. and Pearce, James E. "The Effect of the Federal National Mortgage Association and the Federal Home Loan Mortgage Corporation on Conventional Fixed-Rate Mortgage Yields," in Studies in Privatizing Fannie Mae and Freddie Mac. Washington, DC: U.S. Department of Housing and Urban Development, Office of Policy Development and Research, 1996.

DiPasquale, Denise and Glaeser, Edward L. "Incentives and Social Capital: Are Homeowners Better Citizens?" Journal of Urban Economics, March 1999, 45(2), pp. 354-84.

Doan, Mason C. American Housing Production: 1880-2000. Lanham, MD: University Press of America, 1997.

Federal Home Loan Mortgage Corporation (Freddie Mac). Financing America's Housing: The Vital Role of Freddie Mac. McLean, VA: 1996.

Frame, W. Scott and White, Lawrence J. "Fussing and Fuming Over Fannie and Freddie: How Much Smoke, How Much Fire?" Journal of Economic Perspectives, Spring 2005, 19(2), pp. 159-84.

Goodman, John L. and Nichols, Joseph B. "Does FHA Increase Home Ownership or Just Accelerate It?” Journal of Housing Economics, June 1997, 6(2), pp. 184-202.

Green, Richard and Wachter, Susan. "The American Mortgage in Historical and International Context." Unpublished paper, 2005.
Green, Richard and White, Michelle. "Measuring the Benefits of Homeowning: Effects on Children." Journal of Urban Economics, May 1997, 41(3), pp. 441-61.

Gyourko, Joseph and Hu, Dapeng. "Spatial Distribution of Affordable Home Loan Purchasers in Major Metropolitan Areas: Documentation and Analysis." Regional Science and Urban Economics, September 2002, 32(5), pp. 549-89.

Haar, Charles, M. Federal Credit and Private Housing. New York: McGraw-Hill, 1960.

Haurin, Donald R.; Parcel, Toby L. and Haurin, R. Jean. "Impact of Homeownership and Child Outcomes," in Nicolas P. Retsinas and Eric S. Belsky, eds., Low-Income Homeownership: Examining the Unexamined Goal. Washington, DC: Brookings Institution Press, 2002, pp. 427-46.

Hendershott, Patrick H. and Shilling, James D. “The Impact of the Agencies on Conventional Fixed-Rate Mortgage Yields." Journal of Real Estate Finance and Economics, June 1989, 2(2), pp. 101-15.

Hermalin, Benjamin and Jaffee, Dwight. "The Privatization of Fannie Mae and Freddie Mac: Implications for Mortgage Industry Structure,” in Studies on Privatizing Fannie Mae and Freddie Mac. Washington, DC: HUD, 1996, pp. 225-302.

Heuson, Andrea; Passmore, Wayne and Sparks, Roger. "Credit Scoring and Mortgage Securitization: Implications for Mortgage Rates and Credit Availability." Journal of Real Estate Finance and Economics, November 2001, 23(3), pp. 337-64.

ICF Incorporated. "Effects of the Conforming Loan Limit on Mortgage Markets.” Report prepared for the U.S. Department of Housing and Urban Development, Office of Policy Development and Research. Fairfax, VA: 1990.

Jaffee, Dwight. "The Interest Rate Risk of Fannie Mae and Freddie Mac." Journal of Financial Services Research, August 2003, 24(1), pp. 5-29.

Jaffee, Dwight. "On Limiting the Retained Mortgage Portfolios of Fannie Mae and Freddie Mac.” 


\section{Quigley}

Working Paper 294, University of California, Berkeley, Fisher Center, 2005.

Kain, John F. and Quigley, John M. Housing Markets and Racial Discrimination: A Microeconomic Analysis. New York: Columbia University Press, 1975.

Lafayette, William C.; Haurin, Donald R. and Hendershott, Patric H. "Endogenous Mortgage Choice, Borrowing Constraints, and the Tenure Decision.” NBER Working Paper 5074, National Bureau of Economic Research, 1995.

Lea, Michael J. "Privatizing a Government-Sponsored Enterprise: Lessons from the Sallie Mae Experience." Unpublished manuscript, 2005.

Lehnert, Andreas; Passmore, Wayne and Sherlund, Shane M. "GSEs, Mortgage Rates, and Secondary Market Activities.” Working Paper 2005-07, Board of Governors of the Federal Reserve System, 2005.

Lucas, Deborah and McDonald, Robert. "An OptionsBased Approach to Evaluating the Risk of Fannie Mae and Freddie Mac." Unpublished manuscript, August 2005.

McGarvey, Mark G. and Meador, Mark. "Mortgage Credit Availability, Housing Starts, and the Integration of Mortgage and Capital Markets.” AREUEA Journal, 1991, 19(1), pp. 25-40.

McKenzie, Joseph A. "A Reconsideration of the Jumbo/Non-Jumbo Mortgage Rate Differential." Journal of Real Estate Finance and Economics, September-December 2002, 25(2/3), pp. 197-214.

Monroe, Albert. "How the Federal Housing Administration Affects Homeownership." Unpublished manuscript, 2001.

Munnell, Alicia; Tootell, Geoffrey M.B.; Browne, Lynn E. and McEaney, James. "Mortgage Lending in Boston: Interpreting HMDA Data." American Economic Review, March 1986, 86(1), pp. 25-53.

Naranjo, Andy and Toevs, Alden L. "The Effects of Purchases of Mortgages and Securitization of Government-Sponsored Enterprises on Mortgage
Yield Spreads and Volatility." Journal of Real Estate Finance and Economics, September-December 2002, 25(2-3), pp. 173-96.

Nothaft, Frank E.; Pearce, James E. and Stevanovic, Steven. "Debt Spreads Between GSEs and Other Corporations." Journal of Real Estate Finance and Economics, September-December 2002, 25(2/3), pp. 151-72.

Passmore, Wayne. "The GSE Implicit Subsidy and the Value of Government Ambiguity." Real Estate Economics, Fall 2005, 33(3), pp. 465-86.

Passmore, Wayne; Sherlund, Shane M. and Burgess, Gillian. "The Effect of Housing GovernmentSponsored Enterprises on Mortgage Rates.” Real Estate Economics, Fall 2005, 33(3), pp. 427-63.

Passmore, Wayne; Sparks, Roger and Ingpen, Jamie. "GSEs, Mortgage Rates, and the Long-Run Effects of Mortgage Securitization." Journal of Real Estate Finance and Economics, September-December 2002, 25(2/3), pp. 215-42.

Pearce, James E. Conforming Loan Differentials: 1992-1999. College Station, TX: Welch Consulting, 2000.

Pearce, James E. and Miller, James C. Freddie Mac and Fannie Mae: Their Funding Advantages and Benefits to Consumers. McLean, VA: Freddie Mac, 2001.

Peek, Joe and Wilcox, James A. "Secondary Mortgage Markets, GSEs, and the Changing Cyclicality of Mortgage Flows," in Andrew H. Chen, ed., Research in Finance. Volume 20. New York: Elsevier Press, 2003.

Peek, Joe and Wilcox, James A. "GSEs, Secondary Mortgage Markets, and the Cyclicality of Housing Markets.” Unpublished manuscript, 2004.

Perli, Roberto and Sack, Brian. "Does Mortgage Hedging Amplify Movements in Long-Term Interest Rates?" Journal of Fixed Income, December 2003, 13(3), pp. 7-17.

Poole, William, “GSE Risks.” Federal Reserve Bank 
of St. Louis Review, March/April 2005, 87(2), pp. 85-91.

Ross, Stephen L. and Yinger, John. The Color of Credit: Mortgage Discrimination Research Methodology, and Fair Lending Enforcement. Cambridge, MA: MIT Press, 2002.

Rudolph, Patricia M. and Griffith, John. "Integration of the Mortgage Market into the National Capital Market." Journal of Housing Economics, June 1997, 6(2), pp. 164-83.

Savage, Howard A. and Fronczek, Peter J. Who Can Afford to Buy a House in 1991? Current Housing Reports H121/93-3, U.S. Bureau of the Census, 1993.

Toevs, Alden L. A Critique of the CBO's Sponsorship Benefit Analysis. New York: First Manhattan Consulting Group, 2000.

U.S. Department of the Treasury. Government Sponsorship of the Federal National Mortgage Association and the Federal Home Loan Mortgage Corporation. Washington, DC: GPO, July 1996.

Vandell, Kerry D. "FHA Restructuring Proposals: Alternatives and Implications." Housing Policy Debate, 1995, 6(2), pp. 299-393.

Weicher, John C. "The New Structure of the Housing Finance System.” Federal Reserve Bank of St. Louis Review, July/August 1994, 76(4), pp. 47-65.

Woodward, Susan E. "Recharting Freddie and Fannie: The Policy Issues." Unpublished manuscript, 2004a.

Woodward, Susan E. "Estimating the Jumbo Rate Premium with Clean and Rich Loan Level Data." Unpublished manuscript, Sand Hill Econometrics, 2004b. 
